\title{
Therapeutic Roles of Silymarin or/and Taurine on Nonalcoholic Fatty Liver Disease Associated with Metabolic Syndrome in Rats
}

\author{
Zahran, F.M.; Shahin, M.I.; Kelada, N.A. and Heibashy, D.M.I. \\ Zoology Department, Faculty of Women for Arts, Science and Education , Ain Shams \\ University.
}

\begin{abstract}
Non-alcoholic fatty liver disease (NAFLD) represents one of the most common liver diseases. It is strongly associated with obesity and insulin resistance and thought to be parameters of the metabolic syndrome. NAFLD can progress to non-alcoholic steatohepatitis then to cirrhosis and liver failure. This study aimed to investigate whether silymarin or/and taurine can improve non-alcoholic fatty liver in an animal model and whether this therapeutic approach can result amelioration in carbohydrates profile (serum glucose, insulin, insulin resistance index and hepatic glycogen), lipids profile (serum cholesterol, triglycerides, free fatty acids, leptin and adiponectin as well as hepatic total lipids \& cholesterol), liver function profile (serum aspartate transaminase, alanine transaminase, total protein, albumin and haptoglobin) and the cytokines profile (serum tumor necrosis factor- $\alpha$, interleukin-1 $\beta$ and interleukin-6). The obtained results revealed a significant $(\mathrm{p}<0.001)$ increase in carbohydrates profile (glucose, insulin, insulin resistance index \& hepatic glycogen) in NAFLD rats than those in their control ones. Similary, lipid parameters (serum cholesterol, triglycerides, free fatty acids and leptin as well as hepatic total lipids \& cholesterol) and liver function tests (serum aspartate transaminase, alanine transaminase and haptoglobin)were significantly $(\mathrm{p}<0.001)$ elevated in NAFLD rats compared with their corresponding control group. On the other hand, induction of NAFLD to rats caused a significant $(\mathrm{p}<0.001)$ decrease in adiponectin level with a remarkable decrease in serum total protein and albumin.

A considerable $(\mathrm{p}<0.001)$ elevation were occurred in all cytokines parameters (serum tumor necrosis factor- $\alpha$, interleukin- $1 \beta$ and interleukin-6) in NAFLD rats group compared with their corresponding control group.

When, NAFLD rats group was treated with silymarin or/and taurine, a considerable amelioration effects in all previous studied parameters were pronounced dependent on certain mechanisms and time of treatment.

In conclusion, silymarin or/and taurine reduced metabolic abnormalities associated with NAFLD via inhibition the oxidative stress, increment in the stabilization of mitochondrial membrane, reduction the lipid accumulation in the liver, enhancement in the endoplasmic reticulum (ER) and improving insulin resistance. Overall, silymarin and taurine may be considered as promising and novel therapies for the treatment of NAFLD.
\end{abstract}

Key Words: Non-Alcoholic Fatty Liver Disease, Metabolic Syndrome ,Silymarin ,Taurine ,Rats. 


\section{INTRODUCTION}

Metabolic disorders related to excess nutrient intake have been on the rise in recent decades (Angulo, 2002). Increased incidences of metabolic syndrome, obesity and type II diabetes have also lead to an increased awareness of the significance of co-morbidities associated with these diseases, one of which is nonalcoholic fatty liver disease (Khedmat \& Taheri, 2011 and Possamai et al., 2014). Nonalcoholic fatty liver disease (NAFLD) is a metabolic-related disorder characterized by fat infiltration of the liver in the absence of chronic alcohol consumption (Targher et al., 2008; Watanabe et al., 2008 and Kulkarni et al., 2012). Clinically, NAFLD encompasses a broad spectrum of hepatic derangements ranging from fat accumulation (steatosis) to severe inflammation and fibrosis (nonalcoholic steatohepatitis; NASH) that can lead to cirrhosis (Xirouchakis et al., 2008). Recent estimates suggest that up to $30 \%$ of the general population have some forms of NAFLD and up to $75 \%$ of patients with obesity and diabetes mellitus have NAFLD (Angulo, 2002; Watanabe et al., 2008 and Possamai et al., 2014).

The increase in consumption of high calorie diets, specifically through refined carbohydrates or/and fructose, positively correlates with an alarming increase in obesity, type II diabetes and NAFLD (Ouyang et al., 2008). Moreover, NAFLD has been convincingly associated with the metabolic syndrome and insulin resistance. Insulin resistance, through inhibition of lipid oxidation and increased fatty acids and triglycerides synthesis, is believed to be a key factor in the development of fatty liver (Xirouchakis et al., 2008). Moreover,(Ong et al. 2008), on the other hand, reported that insulin resistance is also characterized by altered production of adipokines variables such as adiponectin, leptin, resistin and tumor necrosis factor- $\alpha$ (TNF- $\alpha$ ).

Basic scientific research has uncovered the mechanisms by which some plants afford their therapeutic effects. Silymarin has been shown to have clinical applications in the treatment of toxic hepatitis, fatty liver, cirrhosis, ischemic injury, radiation toxicity and viral hepatitis via its anti-oxidative, anti-lipid peroxidative, anti-fibrotic, anti-inflammatory, immuno-modulating and liver regenerating effects (Schattenberg \& Galle, 2010; Aghazadeh et al., 2011; Hebbard \& George, 2011 and Elitok, 2012). Hepatoprotective activity of silymarin has been demonstrated by various researchers from all over the world against partial hepatectomy models and toxic models in experimental animals by using carbon tetrachloride (Girish \& Pradhan, 2012) ethanol (Renganathan, 1999), Dgalactosamine (Datta et al., 1999) and Amanita phalloides toxin (Kosina et al., 2002).

Taurine, or 2-aminoethonesulfonic acid, is an organic acid. It is also a major constituent of bile (Bellantini et al., 1987) and can be found in the lower intestine and in small amounts in the tissues of many animals as well as human. Taurine is a derivative of the sulfur-containing (sulfhydryl) amino acid, cysteine. It is one of the few known naturally occurring sulfonic acids. 
Taurine showed significant hypolipidemic and hypocholesterolemic effects (Gentile et al., 2011; Kim et al., 2012 and Rashid et al., 2013), hypoglycemic agent (Go et al., 2001) and cytoprotective effect against hepatocellular damage as well as liver lipid accumulation in NAFLD in man (Xiao et al., 2008) and experimental animals (Chen et al., 2006 and Allen, 2010).

The aim of the current investigation is to evaluate the effect of intake of silymarin or/and taurine on improving several biochemical and immunological parameters in nonalcoholic fatty liver disease in male rats as animal model.

\section{Materials and Methods}

Seventy adult male albino rats (Rattus rattus) approximately of the same age $(12 \pm 1$ week old) and weight $(200 \pm 10 \mathrm{~g})$ were obtained from the Breeding unit, Serum and Antigen Laboratories at Helwan and employed in this investigation. They were caged in wire bottom galvanized metal wall boxes under controlled environmental conditions and were provided with diet and tap water ad libitum for one week prior to the experiment for adaptation.

At the beginning of the experiment, the rats were randomly and unequelly divided into two main groups according to the type of diet. In the first group (normal control rats group), twenty (20) rats were fed on a control diet, containing 60\% corn starch, $20 \%$ casein, $0.7 \%$ methionine, $5 \%$ corn oil, $10.6 \%$ wheat bran, $3.5 \%$ salt mixture and $0.2 \%$ vitamin mixture and served as control. While, in the second group (NAFLD rats group), fifty (50) rats were fed on the same previous diet except that corn starch was replaced with an equal amount of fructose (30\%) and lard (30\%) according to (Du Vigneaud \& Karr 1925) and approved by (Pooranaperundevi et al.2010).

After one month, ten rats from each previous group were taken to compare the alterations in the profiles of serum carbohydrate, lipid and hormones associated with changes in both liver carbohydrate and lipid profiles to assure the induction of NAFLD in rats.

From the remaining rats (50), five comparisons were made between normal control rats (10 rats) and four equal subgroups of rats (40 rats) with experimentally NAFLD. The first experimentally NAFLD subgroup was served as recovery group. The second NAFLD subgroup was treated intragastrically with $1 \mathrm{~g}$ silymarin/kg body weight for 2 months according to (El-Sheikh \& Abd El-Fattah 2011) and served as silymarin subgroup. The third NAFLD subgroup was injected intraperitoneally (i.p) with 500mg taurine/kg body weight according to (Chen et al. 2006) with a little modification with (Xiao et al. 2008) for 2 months and served as taurine subgroup. The fourth NAFLD subgroup rats were received both silymarin and taurine for the same previous dose and period. The rats in the five subgroups were divided into two intervals (one and two months; five rats in each interval).

At the end of each experimental period, rats were slightly anaesthetized by diethyl ether. Fasting blood samples were collected from the heart in clean dry test 
centrifuge tubes, they were centrifuged at $10,000 \mathrm{rpm}$ for 20 minutes and sera were separated and kept at $-20^{\circ} \mathrm{C}$ for analysis of the parameters.

Rats were then sacrificed and immediately livers were removed aseptically, washed with saline solution $(0.9 \% \mathrm{NaCl})$ and kept at $-20^{\circ} \mathrm{C}$ till investigations.

Serum glucose, total cholesterol, triglycerides, free fatty acids, total protein and albumin concentrations were estimated colorimetrically using commercial kits from Prolabo Co. (France). Serum aspartate aminotransferase (AST) and alanine aminotransferase (ALT) activities were determined colorimetrically using commercial kits from DiaChem Ltd., Budapest, Hungary. Serum insulin, leptin, adiponectin, haptoglobin, tumor necrosis factor- $\alpha$, interleukin- $1 \beta$ and interleukin- 6 levels were assayed using commercial ELISA (Sandwich Immunoassay Technique) specific kit for rats (Diagnostic Automation, INC. USA). The homeostatic model assessment (HOMA) value as a measure of insulin resistance (IR) was calculated using the following formula: fasting insulin $(\mu \mathrm{U} / \mathrm{L}) \times$ fasting glucose $(\mathrm{mmol} / \mathrm{L}) / 22.5$ (Matthews et al., 1985).

The glycogen kit is a convenient assay to measure glycogen levels in biological samples according to (Joseph et al. 1961). This kit was purchased from BioVision Research Products Co. (USA).

The liver total lipids and cholesterol concentrations were estimated using commercial kits from Prolabo Co. (France).

Data were statistically analyzed using Student " $t$ " test in the first experimental to evaluate the difference in parameters tested herein between experimentally NAFLD in rats and normal control rats in the preliminary experiment according to (Milton et al. 1986) using a computer program (Costate). Values of $\mathrm{P}<0.001$ were considered statistically significant. However, Two Way Analysis of Variance (ANOVA) followed by Duncan's multiple range test was used in the second experiment according to (Duncan 1955 and Snedecor \& Cochran 1982) to measure the differences in the variables dependent on both time and treatment.

\section{Results and Discussion}

The role of insulin resistance in NAFLD is complex. Both hepatic and systemic insulin resistances are strongly associated with NAFLD. In a fatty liver the ability of insulin to inhibit hepatic glucose production is impaired leading to hyperglycemia and further insulin resistance (Tilg \& Moschen, 2008 and Onnerhag et al., 2013). There is no world-wide standardized cut-off level for HOMA-IR in diagnosing insulin resistance and the insulin assay differs between countries. According to the WHO criteria for the metabolic syndrome, insulin resistance is defined as the lowest $25 \%$ glucose uptake in the background population in the hyperinsulinemic euglycemic clamp (Eckel et al., 2005).

Non-alcoholic fatty liver disease (NAFLD) is the hepatic pandemic of the $21^{\text {th }}$ century, being the number one cause of chronic hepatic disease in the occidental world (Cusi, 2012; Machado \& Cortez-Pinto, 2013 and Mauss et al., 2014). They are closely associated with obesity, type II diabetes mellitus and metabolic syndrome. The epidemics of diabetes and obesity have also fueled an increasing prevalence of 
fatty liver disease. Moreover, NAFLD is associated with an often asymptomatic elevation of serum ALT and gamma glutamyl transferase $(\gamma \mathrm{GT})$ (Elitok, 2012; Xiao et al., 2013; Brumbaughff \& Friedmanff, 2014 and Sookoian \& Pirola, 2014). NAFLD may progress to NASH with fibrosis, cirrhosis and hepatocellular carcinoma (Haddad et al., 2011 and Elitok, 2012). The term NASH was introduced in a description of 20 Mayo Clinic patients with a hitherto unnamed disease associated with hepatomegaly, abnormal ALT, a fatty liver histology, lobular hepatitis and fibrosis mimicking alcoholic hepatitis in the absence of alcohol intake. Most patients had obesity and diabetes mellitus (Ludwig et al., 1980).

In the current study, NAFLD rats group recorded a significant $(\mathrm{p}<0.001)$ elevation in the levels of serum glucose and insulin associated with a significant increment in the value of insulin resistance (HOMA-IR) as compared to their corresponding control group (Table 1). These results may be due to a defect in insulin binding caused by decreasing receptors number or their affinity; changes in Toll-like receptors (TLRs) accompanied with elevation in the pro-inflammatory cytokines (TNF- $\alpha$, IL-1ß and IL-6) or/and defects at the level of effect molecules such as glucose transporters and activities of their enzymes involved in glucose metabolism. Judging from the data presented in this work, similar results were obtained by (Chen et al. 2006; Brumbaughff \& Friedmanff (2014); Rezazadeh \& Yazdanparast 2014 and Sookoian \& Pirola 2014).

The increment in the concentrations of glucose and insulin in NAFLD rats group (Table 1) may be due to the failure of insulin to inhibit hepatic gluconeogenesis and glycogenolysis which are to a large extent responsible for the development of fasting hyperglycaemia and persistent stimulation of insulin production by pancreatic $\beta$-cells (Bogdanova et al., 2006). So, the elevation in the value of HOMA (Insulin resistance) may be attributed to disturbance in the PKB/Akt pathway and to inhibition in the activation of the forkhead transcription factor (FOXO-1).

In this investigation, the elevation in the content of glycogen in NAFLD rats group was pronounced and recorded in Table (1). The percentage of this increase was reached to 79.82. These data may be due to the increment in the HOMA value and hepatic diacylglycerol (DAG) content associated with disturbance in circulating adipocytokines (leptin and resistine) levels and significant lower levels of GSH pool in the hepatocytes as a result of decline in activities of the glyoxalases I and II than those of their corresponding ones.

These results are parallel with Samuel et al. (2004 \& 2007), who recorded that the liver glycogen content was increased in the liver of NAFLD group as compared to normal group. The authors referred these results to the elevations in the level of free fatty acids which inhibits carbohydrate oxidation, insulin-stimulated glucose uptake and its incorporation into glycogen due to a decrease in the activity of glycogen synthase. The disturbance in fatty acid partitioning could contribute to insulin resistance due to the inhibition of cytosolic long-chain fatty acyl (LCFA) CoA oxidation. The mechanism involves malonyl-CoA, which inhibits carnitine palmitoyltransferase (CPT). CPT controls the transfer of LCFA acyl-CoA from the 
cytosol into the mitochondria where they are oxidized. There is an association between elevations of malonyl-Co-A and insulin resistance (Heibashy et al., 2013).

There is now much emerging evidence that chronic consumption of highfructose diets contributes to excessive formation of reactive oxygen species (ROS). This leads to induced oxidative stress and mediated insulin resistance (Houstis et al., 2006). Moreover, an increase in cellular ROS accumulation directly triggers the activation of serine/threonine kinase cascades such as c-Jun $\mathrm{N}$-terminal kinase and nuclear factor-kappa $B\left(\mathrm{NF}-\mathrm{K}_{\beta}\right)$ that, in turn, phosphorylate multiple targets, including the insulin receptor and the insulin receptor substrate (IRS). Increased serine phosphorylation of IRS directly decreases its ability to undergo tyrosine phosphorylation and accelerate the degradation of IRS-1, causing impaired glucose uptake in muscle, liver and adipose tissues (Yao et al., 2011).

In the current study, administration of high carbohydrate (30\% fructose)-high fat diet $(30 \%$ lard) for one month to induce NAFLD in rats caused a significant increment in serum total cholesterol, triglycerides and free fatty acids as compared to their corresponding normal fed rats (Table-1). These results may be due to the increment in the free radicals production which led to alteration in the mitochondrial function (Less in the number, decrease the size and deformation in the shape) associated with alteration in the function of smooth ER due to the elevation in the lipid oxidation. Also, the increment in serum total cholesterol, triglycerides and free fatty acids may be due to the increment in the de nove lipogenesis, change in Niemann-Pick C1-like 1 (NPC1L1) gene expression which has been shown to play a pivotal role in cholesterol absorption (Loss of NPC1L1 expression has been shown to protect against diet-induced fatty liver), disturbance in the hypothalamus-pituitarythyroid axis (HPTA), alteration in the neuropeptide-Y (NPY), orexin A (OX-A) and orexin $\mathrm{B}(\mathrm{OX}-\mathrm{B})$, elevation of ceramides levels or/and the decrease of $\beta$-oxidation of lipid in the matrix of mitochondria. These results are in agreement with the viewpoint that mitochondrial dysfunction participates (Number, size and shape) in the pathogenesis of NAFLD at different levels, mainly including lipid oxidation impairment and the induction of peroxidative production (Heibashy et al.; 2010; Yao et al., 2011; Mauss et al., 2014 and Sookoian \& Pirola, 2014).

In fact, insulin and glucose both drive lipogenesis by respective transcription factors, sterol regulatory element binding protein 1c (SREBP-1c) and carbohydrateresponsive element binding protein (ChREBP). Hyperinsulinemia despite insulin resistance induces the expression of SREBP-1c, a transcriptional activator of all lipogenic enzymes, resulting in increased rate of fatty acid synthesis (Shimomura et al., 1999). Overexpression of SREBP-1c in transgenic mice livers leads to classic fatty liver due to increase lipogenesis (Shimano et al., 1997).

In addition to insulin, glucose activates lipogenesis through transcriptional factor carbohydrate-responsive element binding protein (ChREBP). ChREBP simultaneously activates liver-type pyruvate kinase (L-PK), key regulator of glycolysis and all lipogenic genes (Uyeda et al., 2002), including acetyl-CoA carboxylase and fatty acid synthase (Ishii et al., 2004). 
Cholesterol is either synthesized de novo in the liver or delivered to the liver by lipoproteins (Ginsberg et al., 2005). The metabolism of cholesterol in NAFLD remains poorly explored, insulin resistance is associated with increased cholesterol synthesis (Gylling et al., 2010). Recent metabolomic analysis implicated that cholesterol synthesis in NAFLD patients is increased, in contrast to diminished absorption of cholesterol (Simonen et al., 2011). The expression of cholestrogenic genes was also found elevated in NAFLD patients, accompanied by decreased SREBP-2 and LDLR expression (Olofsson et al., 2000). In rodents, excess cholesterol intake contributes to the development of NAFLD even in the absence of obesity (Matsuzawa et al., 2007).

Table (1): A comparison between normal and non-alcoholic fatty liver disease (NAFLD) rats groups on carbohydrate, lipid, liver function and cytokines profiles related to insulin resistance (Mean $\pm \mathrm{SE}$ ).

\begin{tabular}{|c|c|c|c|c|}
\hline \multicolumn{2}{|c|}{ Parameters } & $\begin{array}{c}\text { Control } \\
\mathbf{n}=\mathbf{1 0}\end{array}$ & $\begin{array}{c}\text { NAFLD } \\
\mathbf{n}=10\end{array}$ & $\begin{array}{c}\% \text { of } \\
\text { change }\end{array}$ \\
\hline \multirow{4}{*}{ 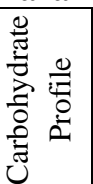 } & Serum glucose $(\mathrm{mmol} / \mathrm{L})$ & $4.592 \pm 0.067$ & $7.853 \pm 0.109^{*}$ & 71.01 \\
\hline & Serum insulin $(\mu \mathrm{U} / \mathrm{ml})$ & $40.736 \pm 1.217$ & $79.129 \pm 1.908^{*}$ & 94.25 \\
\hline & HOMA & $8.121 \pm 0.117$ & $27.034 \pm 0.531^{*}$ & 232.89 \\
\hline & Liver glycogen (mg/100mg wet tissue) & $7.127 \pm 0.084$ & $12.816 \pm 0.152^{*}$ & 79.82 \\
\hline \multirow{7}{*}{ 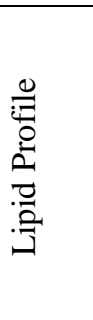 } & Serum cholesterol $(\mathrm{mg} / \mathrm{dL})$ & $55.873 \pm 0.839$ & $109.407 \pm 1.478^{*}$ & 95.81 \\
\hline & Serum triglycerides $(\mathrm{mg} / \mathrm{dL})$ & $64.136 \pm 0.928$ & $137.841 \pm 1.749^{*}$ & 114.92 \\
\hline & Serum free fatty acids $(\mathrm{mmol} / \mathrm{L})$ & $0.623 \pm 0.021$ & $1.718 \pm 0.056^{*}$ & 175.76 \\
\hline & Serum leptin $(\mathrm{ng} / \mathrm{ml})$ & $2.791 \pm 0.032$ & $6.036 \pm 0.078^{*}$ & 116.27 \\
\hline & Serum adiponectin $(\mathrm{ng} / \mathrm{ml})$ & $8.695 \pm 0.141$ & $4.927 \pm 0.087^{*}$ & -43.34 \\
\hline & Liver total lipids (mg/g tissue) & $40.683 \pm 0.671$ & $78.125 \pm 0.934^{*}$ & 92.03 \\
\hline & Liver cholesterol (mg/g tissue) & $2.352 \pm 0.041$ & $4.424 \pm 0.079^{*}$ & 88.10 \\
\hline \multirow{5}{*}{ 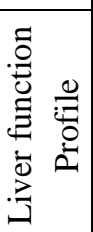 } & AST (U/L) & $121.873 \pm 3.624$ & $202.707 \pm 6.549^{*}$ & 66.33 \\
\hline & ALT (U/L) & $24.136 \pm 1.278$ & $117.841 \pm 3.205^{*}$ & 388.24 \\
\hline & Total protein $(\mathrm{g} / \mathrm{dL})$ & $6.198 \pm 0.077$ & $4.694 \pm 0.061^{*}$ & -24.27 \\
\hline & Albumin $(\mathrm{g} / \mathrm{dL})$ & $3.856 \pm 0.048$ & $2.913 \pm 0.032^{*}$ & -24.46 \\
\hline & Haptoglobin (ng/ml) & $7.116 \pm 0.084$ & $11.652 \pm 0.129^{*}$ & 63.74 \\
\hline \multirow{3}{*}{ 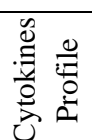 } & Serum TNF-a $(\mathrm{pg} / \mathrm{ml})$ & $5.177 \pm 0.049$ & $11.043 \pm 0.087^{*}$ & 113.31 \\
\hline & Serum IL-1ß (pg/ml) & $3.802 \pm 0.037$ & $6.291 \pm 0.061^{*}$ & 65.47 \\
\hline & Serum IL-6 (pg/ml) & $10.441 \pm 0.075$ & $25.986 \pm 0.121^{*}$ & 148.88 \\
\hline
\end{tabular}

Cholesterol is indispensable, however, toxic in excess. Intracellular level of cholesterol is tightly regulated by a number of mechanisms that govern uptake, synthesis, catabolism and export. Two master regulators of these pathways are the transcription factors SREBP-2 and liver $X$ receptor (LXR). When intracellular cholesterol levels drop, SREBP-2 induces cholesterol biosynthesis and uptake (Brown \& Goldstein, 1997). In contrast, excess intracellular cholesterol inhibits SREBP-2 and activates LXR, which in turn promotes cholesterol export and elimination (Peet et al., 1998).

Leptin is the main regulator of fat in the organism. It is released from the fat tissue into blood then dispensed into the tissues (adipose tissue, peripheral lymphoid tissue, central nervous system, gastrointestinal tract and liver) over the body by 
circulation and combines with its receptors, which then interact with Janus family protein tyrosine kinase/signal transduction and activates transcription factors (JAK/STAT), mainly JAK2/STAT3, to cause the related biological effects (Chitturi et al., 2002) and to exhibit the function of diet control and energy metabolism regulation (Angulo, 2007).

In the current work, serum leptin level was significantly increased in NAFLD rats group as compared to their corresponding control group (Table 1). These results are in agreement with that obtained by Chitturi et al. (2002); Angulo (2007) and Heibashy et al. (2013). However, interesting issues observed that insulin has a direct influence on the synthesis and secretion of leptin (Angulo, 2007 and Heibashy et al., 2013). It is thought that leptin participating in glycol-metabolism and fat-metabolism in liver mainly depends on the regulation of gene expression of phosphoenolpyruvic acid and efficiency of glyconeogenesis which stimulates liver intake of lactic acid and genesis of hepatic glycogen. Simultaneously, it activates the carnitine acyl transferase through protein kinase A, then regulates fat metabolism. Furthermore, leptin interferes with the role of insulin in the liver, on one hand, it counteracts the downregulation of phosphoenolpyruvate carboxykinase (PEPCK) induced by insulin, restrains the phosphorylation of insulin receptor substrate-1 to be involved in the signal transduction; on the other hand, leptin restricts triglyceride synthesis and elevates the insulin sensitivity of liver and peripheral tissues. Leptin can also decrease triglyceride by reducing diet intake (about 50\%) and enhancing energy consumption (Chitturi et al., 2002).

Moreover, adiponectin may protect against NAFLD and steatohepatitis also through its anti-inflammatory action. It is well known that inflammation is a key mechanism in the progression of fatty liver to hepatitis and cirrhosis (Pagano et al., 2006). Adiponectin level is correlating inversely with circulating levels of TNF- $\alpha$ and IL-6 because both these cytokines inhibit adiponectin messenger RNA in adipose tissue (Angulo, 2007). On the other hand, adiponectin induces its anti-inflammatory properties by suppression of IL-6 (Tilg \& Moschen, 2008). Studies of Ota et al. (2008) supported the idea that excessive production of IL-6 versus the defective production of adiponectin may provide a link between insulin resistance and inflammation in NASH. Also, Hui et al. (2004) observed that lower serum adiponectin level in NASH patients was associated with more extensive necroinflammation.

Hepatic total lipid and cholesterol contents were significantly $(p<0.001)$ increased in NAFLD rats group compared to their values in the corresponding normal fed rats group (Table 1). These results seemed to be in complete accordance with several recent studies made by Ota et al. (2008); Bays et al. (2013) and Heibashy et al. (2013). They reported that high fat diets have been shown to increase de novo lipogenesis. This would lead to altering the relative sources of liver triacylglycerol. Fatty acids in the liver come from several different sources: derived from dietary fat, released from adipocytes via lipolysis and from de novo hepatic lipogenesis. An 
imbalance of any of the pathways involved in triacylglycerol delivery, synthesis, export or oxidation could contribute to its accumulation in the liver.

In the current study, hepatic damage in NAFLD rats group was evident from the elevation in the activities of serum AST and ALT associated with a significant decline in the levels of serum total protein and albumin compared to their values in the corresponding normal fed rats groups (Table 1). These biochemical changes reflected the hepatocellular damage including a reduction in the synthetic capacity of the liver in NAFLD rats group. These results may be due to excessive formation of reactive oxygen species (ROS) which leads to induce oxidative stress and mediate insulin resistance associated with considerable decreases in the glutathione content and the activity of glutathione peroxidase and glutathione reductase as well as significant increase in the lipid peroxidation level. The decrease in the levels of serum total protein and albumin in NAFLD rats group may be due to the elevation in the breakdown of SH-bond, disturbance in the endoplasmic reticulum (ER) function, increment in the deamination of amino acid or/and decrease in the activity of AST and ALT in the hepatic cells. These data are in harmony with several recent investigations that reported a significant increase in lipid peroxidation and reduction of hepatic antioxidant enzyme activities in rats fed high fructose diet (Onnerhag et al., 2013; Brumbaughff \& Friedmanff, 2014 and Sookoian \& Pirola, 2014).

Haptoglobin (Hp) is an acute phase protein whose expression increases several folds during inflammation (Nakagawa et al., 2008). It is not surprising to find a significant elevation in the levels of haptoglobin in NAFLD rats group compared to their values in the corresponding normal fed rats groups (Table 1). These data may be due to the elevation of pro-oxidants, increment in the expressions of inflammatory cytokines (TNF- $\alpha$, IL-1ß and IL-6), the over-expressions the genetic polymorphism of haptoglobin (HP) and increasing serum fucosylated haptoglobin (Fuc-Hpt) level, pronouncing of hyperferritinemia associated with changes in the levels of ceruloplasmin and alpha-2-macroglobulin $(\alpha-2 \mathrm{MG})$. These data are in parallel with those obtained by Douali et al. (2014) and Sebastiani et al. (2014).

Cytokines are novel biomarkers for helping in diagnosis of NAFLD. These are dependent on byproducts arising from the pathogenetic mechanisms accompanying inflammation, oxidative stress and liver fibrosis (Choudhuri, 2013) in NAFLD subjects. Cytokines are originating from $\mathrm{T}$ helper 1 (Th1) and $\mathrm{T}$ helper 2 (Th2) subtypes. The main proinflammatory Th1 cytokines are tumor necrosis factor- $\alpha$ (TNF$\alpha$ ), interleukin-1ß (IL-1ß), interleukin-6 (IL-6) and interferon; whereas the main Th2 anti-inflammatory cytokines are IL-4 and IL-10. In general, Th1 induces Th1 cytokines and inhibits Th2 cytokine production and vice versa (Crews et al., 2006). Normally, there is a balance between pro-inflammatory and anti-inflammatory cytokines (Das \& Balakrishnan, 2011).

Judging from the data in Table (1), NAFLD rats group showed a significant $(p<0.001)$ elevation in levels of TNF- $\alpha$, IL-1ß and IL-6 than those of their corresponding ones. These data are in harmony with several recent studies that reported by (Das \& Balakrishnan 2011); Choudhuri (2013); Heibashy et al. (2013); 
Machado \& Cortez-Pinto (2013); Onnerhag et al. (2013) ; Cosma (2014); Douali et al. (2014); Sebastiani et al. (2014) and Wohlfahrt et al. (2014).

The cytokines (TNF- $\alpha$, IL-1 $\beta$ and IL-6) are thought to represent the first step towards the subsequent development of liver fibrosis (Cosma, 2014). Damaged liver cells generate ROS which stimulate the release of pro-inflammatory cytokines like TNF- $\alpha$ from hepatocytes and Kupffer cells thereby increasing the severity of inflammatory stress in the liver (Jaya et al., 2010). Also, because fat accumulates in the liver, there is sustained hepatic generation of pro-inflammatory cytokines from the Kupffer cells, leading to a vicious cycle of worsening insulin resistance and severity of steatohepatitis (Sebastiani et al., 2014). Increased TNF- $\alpha$ production led to suppress insulin receptor signal transduction in fructose-fed rats. Miller \& Adeli (2008) suggested a link between inflammation and insulin resistance. Recent studies also showed that plasma concentrations of TNF- $\alpha$, IL-1ß and IL- 6 were higher in high fructose-fed. Several authors attributed these data to the disturbance in the collagen and hyaluronic acid (HA) levels which are good markers of insulin resistance (Heibashy et al., 2013; Cosma, 2014 and Wohlfahrt et al., 2014).

Table (2): Amelioration effects of silymarin, taurine and their mixture on carbohydrate profile in NAFLD rats (Mean \pm SE).

\begin{tabular}{|c|c|c|c|c|c|c|}
\hline \multicolumn{2}{|c|}{$\begin{array}{l}\text { Groups } \\
\text { Parameters }\end{array}$} & Control & NAFLD & $\begin{array}{l}\text { NAFLD } \\
\text { +Silymarin }\end{array}$ & $\begin{array}{l}\text { NAFLD } \\
\text { +Taurine }\end{array}$ & $\begin{array}{l}\text { NAFLD } \\
+ \text { Mixture }\end{array}$ \\
\hline \multirow[t]{2}{*}{$\begin{array}{l}\text { Glucose } \\
(\mathrm{mmol} / \mathrm{L})\end{array}$} & $\begin{array}{c}1 \text { month } \\
n=5\end{array}$ & $\begin{aligned} & 4.589 \\
& \pm 0.064{ }_{\mathrm{a}}^{\mathrm{A}} \\
&\end{aligned}$ & $\begin{array}{r}7.096 \\
\pm 0.095^{\mathrm{B}} \\
\end{array}$ & $\begin{array}{r}6.197 \\
\pm 0.087^{\mathrm{C}} \\
\end{array}$ & $\begin{array}{r}6.201 \\
\pm 0.089^{\mathrm{C}} \\
\end{array}$ & $\begin{array}{r}5.266 \\
\pm 0.075^{\mathrm{D}} \\
\end{array}$ \\
\hline & $\begin{array}{c}2 \text { months } \\
n=5\end{array}$ & $\begin{array}{r}4.594 \\
\pm 0.065^{\mathrm{A}} \\
\end{array}$ & $\begin{aligned} & 6.084^{\mathrm{B}} \\
& \pm 0.081_{\mathrm{b}}^{\mathrm{b}} \\
&\end{aligned}$ & $\begin{array}{r}5.011 \\
\pm 0.072^{\mathrm{C}} \\
\end{array}$ & $\begin{aligned} & 5.017 \\
& \pm 0.074^{\mathrm{C}} \\
&\end{aligned}$ & $\begin{aligned} & 4.587 \\
& \pm 0.068_{\mathrm{b}}^{\mathrm{A}} \\
&\end{aligned}$ \\
\hline \multirow[t]{2}{*}{$\begin{array}{l}\text { Insulin } \\
(\mu \mathrm{U} / \mathrm{ml})\end{array}$} & $\begin{array}{c}1 \text { month } \\
n=5\end{array}$ & $\begin{array}{r}40.799 \\
\pm 1.358^{\mathrm{A}} \\
\end{array}$ & $\begin{array}{r}70.119 \\
\pm 1.859^{\mathrm{B}} \\
\end{array}$ & $\begin{array}{r}61.748 \\
\pm 1.619^{\mathrm{C}} \\
\end{array}$ & $\begin{array}{r}64.028 \\
\pm 1.723^{\mathrm{D}} \\
\end{array}$ & $\begin{array}{r}55.216 \\
\pm 1.509^{\mathrm{E}} \\
\end{array}$ \\
\hline & $\begin{array}{c}2 \text { months } \\
n=5\end{array}$ & $\begin{aligned} & 41.02 \\
& \pm 1.372^{\mathrm{A}} \\
&\end{aligned}$ & $\begin{array}{r}61.023^{\mathrm{a}} \\
\pm 1.674_{\mathrm{b}}^{\mathrm{B}} \\
\end{array}$ & $\begin{aligned} & 50.902 \\
& \pm 1.528^{\mathrm{C}}{ }_{\mathrm{b}} \\
&\end{aligned}$ & $\begin{array}{c}55.197 \\
\pm 1.583^{\mathrm{D}}{ }_{\mathrm{b}} \\
\end{array}$ & $\begin{array}{c}45.338 \\
\pm 1.442^{\mathrm{E}}{ }_{\mathrm{b}} \\
\end{array}$ \\
\hline \multirow[t]{2}{*}{ HOMA-IR } & $\begin{array}{c}1 \text { month } \\
n=5\end{array}$ & $\begin{aligned} & 8.256 \\
\pm & 0.123_{\mathrm{a}}^{\mathrm{A}}\end{aligned}$ & $\begin{array}{r}21.171 \\
\pm 0.449^{\mathrm{B}}\end{array}$ & $\begin{array}{c}15.513 \\
\pm 0.374^{\mathrm{C}}\end{array}$ & $\begin{array}{r}16.909 \\
\pm 0.381^{\mathrm{D}}\end{array}$ & $\begin{array}{c}12.661 \\
\pm 0.254^{\mathrm{E}}\end{array}$ \\
\hline & $\begin{array}{c}2 \text { months } \\
n=5\end{array}$ & $\begin{array}{r}8.311^{\mathrm{A}} \\
\pm 0.127_{\mathrm{a}}^{\mathrm{a}}\end{array}$ & $\begin{array}{r}16.869 \\
\pm 0.383^{\mathrm{B}}{ }_{\mathrm{b}} \\
\end{array}$ & $\begin{array}{r}10.129 \\
\pm 0.227^{\mathrm{C}} \\
\end{array}$ & $\begin{array}{r}12.612 \\
\pm 0.231^{\mathrm{D}}{ }_{\mathrm{b}} \\
\end{array}$ & $\begin{array}{c}8.403 \\
\pm 0.149^{\mathrm{A}} \mathrm{b} \\
\end{array}$ \\
\hline \multirow{2}{*}{$\begin{array}{c}\begin{array}{c}\text { Liver } \\
\text { glycogen }\end{array} \\
\text { (mg/100mg } \\
\text { wet tissue) }\end{array}$} & $\begin{array}{c}1 \text { month } \\
\mathrm{n}=5\end{array}$ & $\begin{array}{r}7.131 \\
\pm 0.085^{\mathrm{A}} \\
\end{array}$ & $\begin{array}{r}11.788 \\
\pm 0.134^{\mathrm{B}} \\
\end{array}$ & $\begin{array}{r}9.088 \\
\pm 0.118^{\mathrm{C}} \\
\end{array}$ & $\begin{array}{r}9.103 \\
\pm 0.121_{\mathrm{a}}^{\mathrm{C}} \\
\end{array}$ & $\begin{aligned} & 8.575 \\
& \pm 0.101^{\mathrm{D}} \\
&\end{aligned}$ \\
\hline & $\begin{array}{c}2 \text { months } \\
n=5\end{array}$ & $\begin{array}{r}7.136 \\
\pm 0.088^{\mathrm{A}} \mathrm{a} \\
\end{array}$ & $\begin{array}{r}10.723 \\
\pm 0.123^{\mathrm{B}} \\
\end{array}$ & $\begin{aligned} & 8.002 \\
& \pm 0.094^{\mathrm{C}}{ }_{\mathrm{b}} \\
&\end{aligned}$ & $\begin{aligned} & 8.016 \\
& \pm 0.096^{\mathrm{D}} \\
&\end{aligned}$ & $\begin{array}{r}7.208 \\
\pm 0.084^{\mathrm{A}} \\
\end{array}$ \\
\hline
\end{tabular}

$\mathrm{A}, \mathrm{B}, \mathrm{C}, \mathrm{D}, \mathrm{E}$ Means with a common superscript within a row are significantly different at $(\mathrm{P}<0.05)$.

a, b Means with a common subscript within a column are significantly different at $(\mathbf{P}<0.05)$.

Inflammatory cytokines are important mediators in the development of NAFLD. Among inflammatory cytokines, TNF- $\alpha$ and IL-1 $\beta$ have multiple functions including immune modulation, cell differentiation, proliferation, apoptosis, and energy metabolism. Indeed, expressions of TNF- $\alpha$ and IL- $1 \beta$ are increased in NAFLD patients and animal models (Hui et al., 2004). In contrast, most of TLR-deficient mice show decreased TNF- $\alpha$ and IL-1 $\beta$ levels in NAFLD models (Miura et al., 2010).

TNF- $\alpha$ levels are increased in the liver, the adipose tissue and the serum of NAFLD patients. Expression of TNF receptors is also increased in the liver of 
NAFLD patients. So far, several mechanisms of TNF- $\alpha$-mediated functions are proposed: (1) insulin resistance, (2) release of fatty acids from adipose tissue, (3) regulation of lipid influx and efflux in hepatocytes and (4) hepatocyte cell death (Hui et al., 2004 and Miura et al., 2010).

High fructose/fat diet has become popular in recent years as a model of nonalcoholic fatty liver disease (NAFLD) with pronouncing of metabolic syndrome (Vos \& Lavine, 2013). With the rising interest in complementary and alternative medicine, notably in the western hemisphere, several natural products have raised interest for their potential beneficial effects in liver disease. Among such attractive novel therapeutic possibilities are silymarin and its major active compounds (El-Sheikh $\&$ Abd El-Fattah, 2011; Haddad et al., 2011; Schrieber et al., 2011; Yao et al., 2011; Girish \& Pradhan, 2012; Hajiaghamohammadi et al., 2012; Kim et al., 2012; Rahimi et al., 2012 and Thounaojam et al., 2012). Also, taurine is a small amino sulfonic acid and aids in numerous physiological processes, including bile salt formation, osmoregulation, central nervous system function and calcium homeostasis (Xiao et al., 2008; Chen et al., 2009; Schaffer et al., 2009; Gupta, 2013 and Rashid et al., 2013). Epidemiological data demonstrate that dietary taurine intake is inversely related to the prevalence of metabolic diseases and clinical and experimental studies suggest that taurine supplementation protects against metabolic disturbances, including diabetes and its complications (Bruns et al., 2011 and Gentile et al., 2011).

In the current work, the non-alcoholic fatty liver disease (NAFLD) subgroup rats which treated intragastrically (i.g) with $1 \mathrm{~g}$ silymarin/kg body weight for one and two months recorded significant $(\mathrm{p}<0.05)$ decreases in the levels of serum glucose and insulin as well as in the insulin resistance (HOMA-IR) value associated with a significant decline in the liver glycogen content as shown in Table (2) and these enhancement were dependent on the time of treatment ( $1 \& 2$ months). These data may be attributed to the powerful of pharma-properties of silymarin which acts against the pro-oxidant products mainly through free radical scavenging and the ability to increase cellular GSH content; its ability to regulate membrane permeability and increase membrane stability in the presence of xenobiotic damage; its capacity to regulate nuclear expression through steroid-like effects and its inhibition of the transformation of stellate hepatocytes into myofibroblasts (which mediate the deposition of collagen fibers, leading to fibrosis and cirrhosis). These results are in agreement with those of Haddad et al. (2011); Hajiaghamohammadi et al. (2012) Rahimi et al. (2012) and Thounaojam et al. (2012). Moreover, Saller et al. (2007) recorded that insulin sensitivity was restored by silymarin treatment as suggested by normalized insulinemia and HOMA-IR, despite the continued intake of the NAFLDinducing high fructose/fat diet. This hypoinsulinemic effect was shown in a previous clinical trial on cirrhotic diabetic patients.

As shown in Table (3), supplementation of silymarin (1 $\mathrm{g}$ silymarin/kg body weight intragastrically) after induction of NAFLD to rats showed a significant $(\mathrm{p}<0.05)$ decrease in the serum lipid profile (cholesterol, triglycerides, free fatty acids \& leptin) as well as hepatic total lipids and cholesterol levels associated with a significant increase occurred in the serum adiponectin levels through the whole 
experiment periods (One and two months). These results are in agreement with those of Hajiaghamohammadi et al. (2012) and Thounaojam et al. (2012). They reported that the supplementation of silymarin improves dyslipidemia and decreases oxidative stress. Also, supplementation of silymarin to NAFLD rats reduces significantly serum hypertriglyceridemia via decreased synthesis of triglycerides by the liver or by inhibition of triglycerides release from the liver. Also, the previous scientists reported that the hypolipidemic effects of silymarin on lipid profile via the enhancement in de novo lipogenesis pathway and correction in the mitochondrial transport metabolism of long-chain fatty acids, thus for myocardial energetic metabolism. Fatty acids cross mitochondrial membranes derivatives to enter pathways for oxidation, acylation, chain shortening or chain elongation-desaturation. Therefore, the action of silymarin on fatty acid transfer is central to lipid metabolism and dietary supplementation of silymarin improves the utilization of fat providing marked reduction in serum levels of TG (Schrieber et al., 2011; Yao et al., 2011 and Kim et al., 2012).

Table (3): Amelioration effects of silymarin, taurine and their mixture on lipid profile in NAFLD rats

\begin{tabular}{|c|c|c|c|c|c|c|}
\hline \multicolumn{2}{|c|}{\begin{tabular}{|l} 
Groups \\
Parameters
\end{tabular}} & Control & NAFLD & $\begin{aligned} & \text { NAFLD } \\
&+ \text { Silymarin }\end{aligned}$ & $\begin{array}{l}\text { NAFLD } \\
+ \text { Taurine }\end{array}$ & $\begin{array}{l}\text { NAFLD } \\
+ \text { Mixture }\end{array}$ \\
\hline \multirow[t]{2}{*}{$\begin{array}{l}\text { Cholesterol } \\
(\mathrm{mg} / \mathrm{dL})\end{array}$} & $\begin{array}{c}\text { 1month } \\
n=5\end{array}$ & $\begin{array}{c}55.724 \\
\pm 0.387^{\mathrm{A}} \\
\end{array}$ & $\begin{array}{l}101.582 \\
\pm 1.139^{\mathbf{B}} \\
\end{array}$ & $\begin{array}{r}85.193 \\
\pm 1.024^{\mathrm{C}} \\
\end{array}$ & $\begin{array}{r}90.973 \\
\pm 1.072^{\mathrm{D}} \\
\end{array}$ & $\begin{array}{l}78.326 \\
\pm 0.725^{\mathbf{E}} \\
\end{array}$ \\
\hline & $\begin{array}{c}\text { 2months } \\
n=5\end{array}$ & $\begin{array}{c}56.173 \\
\pm 0.390^{\mathbf{A}} \\
\end{array}$ & $\begin{array}{r}92.017 \\
\pm 1.053^{\mathbf{B}}{ }_{\mathrm{b}} \\
\end{array}$ & $\begin{array}{r}70.284 \\
\pm 0.688_{b} \\
\end{array}$ & $\begin{array}{r}79.362 \\
\pm 0.745^{\mathrm{D}} \\
\end{array}$ & $\begin{array}{r}60.142 \\
\pm 0.563^{E} \\
\end{array}$ \\
\hline \multirow[t]{2}{*}{$\begin{array}{l}\text { Triglycerides } \\
\quad(\mathrm{mg} / \mathrm{dL})\end{array}$} & $\begin{array}{c}\text { 1month } \\
n=5\end{array}$ & $\begin{array}{c}64.589 \\
\pm 0.547_{a}^{\mathrm{A}} \\
\end{array}$ & $\begin{array}{r}129.219 \\
\pm 1.239^{\mathbf{B}} \\
\end{array}$ & $\begin{array}{r}96.455 \\
\pm 0.904_{\text {a }}^{C} \\
\end{array}$ & $\begin{array}{l}108.837 \\
\pm 0.995^{\mathrm{D}} \\
\end{array}$ & $\begin{array}{r}89.649 \\
\pm 0.891_{a}^{E} \\
\end{array}$ \\
\hline & $\begin{array}{c}\text { 2months } \\
n=5\end{array}$ & $\begin{array}{c}65.021 \\
\pm 0.593_{a}^{\mathrm{A}} \\
\end{array}$ & $\begin{array}{r}111.314 \\
\pm 1.051_{b}^{\mathrm{B}} \\
\end{array}$ & $\begin{array}{r}84.118 \\
\pm 0.835^{C} \\
\end{array}$ & $\begin{array}{r}92.192 \\
\pm 0.928_{{ }_{b}}^{D}\end{array}$ & $\begin{array}{r}70.631 \\
\pm 0.708^{E} \\
\end{array}$ \\
\hline \multirow[t]{2}{*}{$\begin{array}{c}\text { Free fatty acids } \\
(\mathrm{mmol} / \mathrm{L})\end{array}$} & $\begin{array}{c}1 \text { month } \\
n=5\end{array}$ & $\begin{array}{r}0.633 \\
\pm 0.073^{\mathrm{A}} \\
\end{array}$ & $\begin{array}{r}1.447 \\
\pm 0.091_{\mathbf{a}}^{\mathbf{B}} \\
\end{array}$ & $\begin{array}{c}1.024 \\
\pm 0.077^{\mathrm{C}} \\
\end{array}$ & $\begin{array}{c}1.297 \\
\pm 0.097^{\mathrm{D}} \\
\end{array}$ & $\begin{array}{c}0.905 \\
\pm 0.076^{\mathbf{E}} \\
\end{array}$ \\
\hline & $\begin{array}{c}2 \text { months } \\
n=5\end{array}$ & $\begin{array}{c}0.637 \\
\pm 0.076_{a}^{\mathrm{A}} \\
\end{array}$ & $\begin{array}{r}1.128 \\
\pm 0.086^{\mathbf{B}}{ }_{b} \\
\end{array}$ & $\begin{array}{c}0.807 \\
\pm 0.072^{C}{ }_{b} \\
\end{array}$ & $\begin{array}{c}0.923 \\
\pm 0.089^{D}{ }_{b} \\
\end{array}$ & $\begin{array}{c}0.716 \\
\pm 0.072^{\mathbf{E}}{ }_{b} \\
\end{array}$ \\
\hline \multirow[t]{2}{*}{$\begin{array}{l}\text { Leptin } \\
(\mathrm{ng} / \mathrm{ml})\end{array}$} & $\begin{array}{c}1 \text { month } \\
n=5\end{array}$ & $\begin{array}{c}2.775 \\
\pm 0.032_{\mathrm{a}}^{\mathrm{A}} \\
\end{array}$ & $\begin{array}{c}5.582 \\
\pm 0.082^{\mathrm{B}} \\
\end{array}$ & $\begin{array}{c}4.104 \\
\pm 0.064_{\mathrm{a}}^{\mathrm{C}} \\
\end{array}$ & $\begin{array}{c}4.842^{2} \\
\pm 0.073^{\mathrm{D}} \\
\end{array}$ & $\begin{array}{c}3.948 \\
\pm 0.052^{\mathrm{E}} \\
\end{array}$ \\
\hline & $\begin{array}{c}2 \text { months } \\
n=5\end{array}$ & $\begin{array}{c}2.806 \\
\pm 0.033^{\mathrm{A}} \\
\end{array}$ & $\begin{array}{c}4.7411^{\mathbf{B}} \\
\pm 0.071^{\mathbf{b}}\end{array}$ & $\begin{array}{c}3.003 \\
\pm 0.059^{C}{ }_{b}\end{array}$ & $\begin{array}{c}3.944 \\
\pm 0.068^{D} \\
\text { b }\end{array}$ & $\begin{array}{c}2.813 \\
\pm 0.041^{\mathrm{A}}{ }_{\mathrm{b}}\end{array}$ \\
\hline \multirow[t]{2}{*}{$\begin{array}{l}\text { Adiponectin } \\
\qquad(\mathrm{ng} / \mathrm{ml})\end{array}$} & $\begin{array}{c}1 \text { month } \\
n=5\end{array}$ & $\begin{array}{c}8.694 \\
\pm 0.143^{\mathrm{A}} \\
\end{array}$ & $\begin{array}{c}5.526 \\
\pm 0.097^{\mathbf{B}} \\
\end{array}$ & $\begin{array}{r}6.505 \\
\pm 0.106^{\mathrm{C}} \\
\end{array}$ & $\begin{array}{c}5.972 \\
\pm 0.096^{\mathrm{D}} \\
\end{array}$ & $\begin{array}{c}6.993 \\
\pm 0.101^{\mathbf{E}} \\
\end{array}$ \\
\hline & $\begin{array}{c}2 \text { months } \\
n=5\end{array}$ & $\begin{array}{c}8.691 \\
\pm 0.142^{\mathrm{A}} \\
\end{array}$ & $\begin{array}{c}6.593 \\
\pm 0.108^{\mathbf{B}} \\
\end{array}$ & $\begin{array}{c}7.877 \\
\pm 0.124_{b}^{C} \\
\end{array}$ & $\begin{array}{c}7.020 \\
\pm 0.117_{b}^{\mathrm{D}} \\
\end{array}$ & $\begin{array}{c}8.725 \\
\pm 0.138_{b}^{\mathrm{A}} \\
\end{array}$ \\
\hline \multirow{2}{*}{$\begin{array}{c}\text { Liver total } \\
\text { lipids } \\
\text { (mg/g tissue) }\end{array}$} & $\begin{array}{c}1 \text { month } \\
n=5\end{array}$ & $\begin{array}{c}40.712^{\mathrm{A}} \\
\pm 0.674_{\mathrm{a}}^{\mathrm{A}}\end{array}$ & $\begin{array}{r}72.438 \\
\pm 0.822^{\mathbf{B}} \\
\end{array}$ & $\begin{array}{r}64.094 \\
\pm 0.771_{\mathrm{a}}^{\mathrm{C}} \\
\end{array}$ & $\begin{array}{r}64.142 \\
\pm 0.773^{C} \\
\end{array}$ & $\begin{array}{c}57.948 \\
\pm 0.762^{\mathrm{D}} \\
\end{array}$ \\
\hline & $\begin{array}{c}2 \text { months } \\
n=5\end{array}$ & $\begin{array}{r}41.806 \\
\pm 0.678_{a}^{\mathrm{A}} \\
\end{array}$ & $\begin{array}{c}65.521 \\
\pm 0.773^{\mathbf{B}}{ }_{b} \\
\end{array}$ & $\begin{array}{r}53.657 \\
\pm 0.719^{C} \\
\end{array}$ & $\begin{array}{c}53.771 \\
\pm 0.728_{b} \\
\end{array}$ & $\begin{array}{c}46.313 \\
\pm 0.689^{D}{ }_{b} \\
\end{array}$ \\
\hline \multirow{2}{*}{$\begin{array}{c}\text { Liver } \\
\text { cholesterol } \\
\text { (mg/g tissue) }\end{array}$} & $\begin{array}{c}1 \text { month } \\
n=5\end{array}$ & $\begin{array}{c}2.354 \\
\pm 0.041_{\mathrm{a}}^{\mathrm{A}} \\
\end{array}$ & $\begin{array}{c}4.098 \\
\pm 0.072^{\mathbf{B}} \\
\end{array}$ & $\begin{array}{c}3.657 \\
\pm 0.062_{\mathrm{a}}^{\mathrm{C}} \\
\end{array}$ & $\begin{array}{c}3.672 \\
\pm 0.066^{\mathrm{C}} \\
\end{array}$ & $\begin{array}{c}3.221 \\
\pm 0.058^{\mathrm{D}} \\
\end{array}$ \\
\hline & $\begin{array}{c}2 \text { months } \\
n=5\end{array}$ & $\begin{array}{c}2.355 \\
\pm 0.043_{a}^{\mathrm{A}} \\
\end{array}$ & $\begin{array}{c}3.719 \\
\pm 0.068^{\mathbf{B}} \\
\end{array}$ & $\begin{array}{c}3.007 \\
\pm 0.051_{b}^{C}\end{array}$ & $\begin{array}{c}3.019 \\
\pm 0.053^{\mathrm{C}} \\
\end{array}$ & $\begin{array}{c}2.661 \\
\pm 0.048^{E} \\
\end{array}$ \\
\hline
\end{tabular}

- A, B, C, D, E Means with a common superscript within a row are significantly different at $(P<0.05)$.

- a, b Means with a common subscript within a column are significantly different at $(P<0.05)$. 
Furthermore, silymarin regulates the turnover of the fatty acids into phospholipids membranes, a process known as the deacylation-reacylation cycle of phospholipids membranes (Girish \& Pradhan, 2012). Silymarin is suggested to act as CoA buffer, maintaining the acyl CoA/CoA ratio in cells and exerts a function in several metabolic processes. The transport of acyl-CoA across the inner mitochondrial membrane to the matrix determines a reduced availability of CoA in the matrix and a decrease of CoASH. It determines a parallel increase in the acyl CoA/CoASH ratio, which inhibits the mitochondrial dehydrogenases; consequently, not only the oxidation of fatty acids but also the utilization of carbohydrates becomes impaired (Schrieber et al., 2011 and Rahimi et al., 2012). Finally, silymarin could exert its antiapoptotic effects by decreasing ROS production, removing toxic fatty acid derivatives and reducing generation of ceramides (El-Sheikh \& Abd El-Fatta, 2011; Haddad et al., 2011; Girish \& Pradhan, 2012 and Kim et al., 2012).

The treatment of NAFLD rats with silymarin led to a significant decrease in the leptin level and a remarkable increase in the adiponectin concentration (Table 3). These results may be due to the improvement in the pro-inflammatory cytokines, increment in the $\beta$-oxidation of fat in the matrix of mitochondria, suppression in the fatty acid synthase (FAS) associated with activations in both acyl-CoA carboxylase (ACC) and carnitine palmitoyltransferase I (CPT-I) as well as modulation in the expression of adiponectin gene. These data may be also attributed to the corrections in the hypothalamus- pituitary-thyroid axis (HPTA) and the production of neuropeptide hormones (Neuropeptide-Y, orexin-A and orexine-B) dependent on the time of treatment (One \& two months). These data were confirmed by several authors (Saller et al., 2007; El-Sheikh \& Abd El-Fatta, 2011; Haddad et al., 2011; Hajiaghamohammadi et al., 2012; Kim et al., 2012 and Thounaojam et al., 2012).

The previous findings coincided with a significant decrease in serum aminotransferases (AST \&ALT) activities after similar intake and in harmony with the results of Aghazadeh et al. (2011); El-Sheikh \& Abd El-Fatta (2011); Haddad et al. (2011) and Zhu et al. (2013).

Also, in the current study, silymarin caused apparent improvement in liver functions as shown in Table (4) by restoring total protein and albumin levels that were decreased by high fructose/fat diet suggesting its immunopromoting effect (El-Sheikh

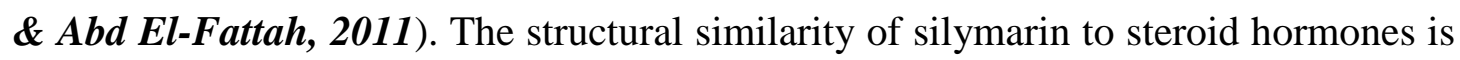
believed to be responsible for its protein synthesis facilitatory actions. Silymarin can enter inside the nucleus and act on RNA polymerase enzymes resulting in increased ribosomal formation. This in turn hastens protein and DNA synthesis. This action has important therapeutic implications in the repair of damaged hepatocytes and restoration of normal functions of liver (Basiglio et al., 2009).

Moreover, the supplementation of silymarin seems to encourage the liver to grow new cells, while discouraging the formation of inactive fibrous tissue. Silymarin acts as cellular guard by changing the outside layer of liver cells and keeping certain harmful chemicals from getting into liver cells. Also, silymarin may also cause the immune system to be more active (Abenavoli et al., 2011; El-Sheikh \& Abd ElFattah, 2011; Haddad et al., 2011; Hajiaghamohammadi et al., 2012; Kim et al., 
2012; Thounaojam et al., 2012 and Zhu et al., 2013). This hypothesis confirmed in the current work with a considerable decrease in the serum haptoglobin level after the NAFLD rats treated with silymarin (Table 4). The amelioration effects may be due to the improvement in the insulin resistance and inhibition in the hepatic stellate cell (HSC) activation due to the block of Mallory bodies production.

Table (4): Amelioration effects of silymarin, taurine and their mixture on serum liver profile in NAFLD rats (Mean \pm SE).

\begin{tabular}{|c|c|c|c|c|c|c|}
\hline \multicolumn{2}{|c|}{\begin{tabular}{|l} 
Groups \\
Parameters
\end{tabular}} & Control & NAFLD & $\begin{array}{c}\text { NAFLD } \\
+ \text { Silymarin }\end{array}$ & $\begin{array}{l}\text { NAFLD } \\
\text { +Taurine }\end{array}$ & $\begin{array}{l}\text { NAFLD } \\
+ \text { Mixture }\end{array}$ \\
\hline \multirow[t]{2}{*}{$\begin{array}{l}\mathbf{A S T} \\
(\mathrm{U} / \mathrm{L})\end{array}$} & $\begin{array}{c}\text { 1month } \\
n=5\end{array}$ & $\begin{array}{l}122.147 \\
\pm 3.631_{\text {a }}^{\mathrm{A}}\end{array}$ & $\begin{array}{l}187.429 \\
\pm 6.012^{\mathrm{B}} \\
\end{array}$ & $\begin{array}{r}169.799 \\
\pm 5.459^{\mathrm{C}} \\
\end{array}$ & $\begin{array}{l}170.445 \\
\pm 5.467^{\mathrm{C}} \\
\end{array}$ & $\begin{array}{r}149.872 \\
\pm 4.665^{D} \\
\end{array}$ \\
\hline & $\begin{array}{l}\text { 2months } \\
n=5\end{array}$ & $\begin{array}{l}124.023 \\
\pm 3.639^{\mathbf{A}} \\
\end{array}$ & $\begin{array}{l}156.017 \\
\pm 5.198^{B} \\
\end{array}$ & $\begin{array}{r}140.778 \\
\pm 4.119^{C}\end{array}$ & $\begin{array}{l}142.333 \\
\pm 4.123^{C}\end{array}$ & $\begin{array}{l}126.009 \\
\pm 3.801^{\mathrm{D}} \\
\end{array}$ \\
\hline \multirow[t]{2}{*}{$\begin{array}{l}\mathbf{A L T} \\
(\mathrm{U} / \mathrm{L})\end{array}$} & $\begin{array}{c}\text { 1month } \\
n=5\end{array}$ & $\begin{array}{c}24.135 \\
\pm 1.274_{\mathrm{a}}^{\mathrm{A}}\end{array}$ & $\begin{array}{c}96.841 \\
\pm 3.013^{\mathbf{B}} \\
\end{array}$ & $\begin{array}{r}82.223 \\
\pm 2.545^{\mathrm{C}} \\
\end{array}$ & $\begin{array}{r}87.538 \\
\pm 2.902^{\mathrm{D}} \\
\end{array}$ & $\begin{array}{r}75.127 \\
\pm 2.131^{\mathbf{E}} \\
\end{array}$ \\
\hline & $\begin{array}{l}\text { 2months } \\
\quad n=5\end{array}$ & $\begin{array}{c}24.139 \\
\pm 1.277^{\mathrm{A}} \\
\end{array}$ & $\begin{array}{l}88.329 \\
\pm 2.898^{\text {B }}{ }_{b}\end{array}$ & $\begin{array}{r}64.906 \\
\pm 1.905^{C} \\
\end{array}$ & $\begin{array}{r}70.436 \\
\pm 2.018_{b}^{\mathrm{D}} \\
\end{array}$ & $\begin{array}{r}53.761 \\
\pm 1.568_{b}^{E} \\
\end{array}$ \\
\hline \multirow[t]{2}{*}{$\begin{array}{l}\text { Total protein } \\
\text { (g/dL) }\end{array}$} & $\begin{array}{c}1 \text { month } \\
n=5\end{array}$ & $\begin{array}{c}6.203 \\
\pm 0.081_{\mathrm{a}}^{\mathrm{A}}\end{array}$ & $\begin{array}{c}4.813 \\
\pm 0.069^{\mathbf{B}} \\
\text { a }\end{array}$ & $\begin{array}{c}5.289 \\
\pm 0.085^{\mathrm{C}} \\
\text { a }\end{array}$ & $\begin{array}{c}5.307 \\
\pm 0.082^{\mathrm{C}} \\
\text { a }\end{array}$ & $\begin{array}{c}5.649 \\
\pm 0.091^{\mathrm{D}}\end{array}$ \\
\hline & $\begin{array}{c}2 \text { months } \\
n=5\end{array}$ & $\begin{array}{c}6.197 \\
\pm 0.079_{a}^{A} \\
\end{array}$ & $\begin{array}{c}5.089 \\
\pm 0.077_{b}^{\mathrm{B}} \\
\end{array}$ & $\begin{array}{c}5.819 \\
\pm 0.072^{C} \\
\end{array}$ & $\begin{array}{r}5.832 \\
\pm 0.089^{C} \\
\end{array}$ & $\begin{array}{r}6.156 \\
\pm 0.081_{b}^{A} \\
\end{array}$ \\
\hline \multirow[t]{2}{*}{$\begin{array}{l}\text { Albumin } \\
(\mathrm{g} / \mathrm{dL})\end{array}$} & $\begin{array}{c}1 \text { month } \\
n=5\end{array}$ & $\begin{array}{c}3.853 \\
\pm 0.047_{\mathrm{a}}^{\mathrm{A}}\end{array}$ & $\begin{array}{c}3.078 \\
\pm 0.037^{\mathbf{B}} \\
\end{array}$ & $\begin{array}{c}3.402 \\
\pm 0.044^{\mathrm{C}} \\
\mathrm{a}\end{array}$ & $\begin{array}{c}3.389 \\
\pm 0.042^{\mathrm{C}}{ }_{\mathrm{a}}\end{array}$ & $\begin{array}{c}3.628 \\
\pm 0.052^{D} \\
a\end{array}$ \\
\hline & $\begin{array}{c}2 \text { months } \\
n=5\end{array}$ & $\begin{array}{c}3.857 \\
\pm 0.048_{\text {a }}^{\mathrm{A}} \\
\end{array}$ & $\begin{array}{c}3.229 \\
\pm 0.041^{\mathrm{B}} \\
\end{array}$ & $\begin{array}{c}3.611 \\
\pm 0.049^{C} \\
\end{array}$ & $\begin{array}{c}3.597 \\
\pm 0.048^{C} \\
\end{array}$ & $\begin{array}{c}3.861 \\
\pm 0.041^{\mathrm{A}}{ }_{\mathrm{b}}\end{array}$ \\
\hline \multirow[t]{2}{*}{$\begin{array}{c}\text { Haptoglobin } \\
(\mathrm{ng} / \mathrm{ml})\end{array}$} & $\begin{array}{c}1 \text { month } \\
n=5\end{array}$ & $\begin{array}{r}7.116 \\
\pm 0.084_{\mathrm{a}}^{\mathrm{A}} \\
\end{array}$ & $\begin{array}{c}11.119 \\
\pm 0.118^{\mathbf{B}} \\
\end{array}$ & $\begin{array}{c}9.778 \\
\pm 0.096^{\mathrm{C}} \\
\end{array}$ & $\begin{array}{r}10.814 \\
\pm 0.113_{a}^{\mathrm{D}} \\
\end{array}$ & $\begin{array}{c}8.622 \\
\pm 0.091^{\mathrm{E}} \\
\end{array}$ \\
\hline & $\begin{array}{c}2 \text { months } \\
n=5\end{array}$ & $\begin{array}{r}7.116 \\
\pm 0.084_{\mathrm{a}}^{\mathrm{A}} \\
\end{array}$ & $\begin{array}{r}9.675 \\
\pm 0.109^{\mathbf{B}}{ }_{b} \\
\end{array}$ & $\begin{array}{c}8.329 \\
\pm 0.093^{C}{ }_{b} \\
\end{array}$ & $\begin{array}{c}9.547 \\
\pm 0.097^{\mathrm{D}} \\
\end{array}$ & $\begin{array}{c}7.725 \\
\pm 0.088^{\mathbf{E}} \\
\end{array}$ \\
\hline
\end{tabular}

- A, B, C, D, E Means with a common superscript within a row are significantly different at $(P<0.05)$.

- a, b Means with a common subscript within a column are significantly different at $(\mathrm{P}<0.05)$.

The hepatoprotective, antioxidant and antifibrogenic in addation to the decline in the cytokines effects of silymarin observed herein are also consistent with previous studies (Jia et al.; 2001; Kidd \& Head, 2005; Victorrajmohan et al., 2005; Terao, 2009 and Haddad et al., 2011). The authors attributed these data to the antioxidant properties of silymarin which led to the decrease in the oxidative stress via Boxidation of fatty acids as well as the decline in the lipotoxicity with reduction in the endotoxin/TLR4 causing a remarkable decrease in the production of cytokines and endoplasmic reticulum (ER) stress and increment in the immune system and cellular enzymes antioxidants. This explanation reflects on the current data of cytokines profile (TNF- $\alpha$, IL-1ß and IL-6) whereas, the supplementation of silymarin (1g silymarin/kg body weight intragastrically) after induction of NAFLD to rats showed a significant $(p<0.05)$ decline in the serum TNF- $\alpha$, IL-1ß and IL-6 (Table 5) dependent on the time of treatment (One \& two months).

Likewise, the hepatoprotective effect of silibinin was confirmed by the normalized level of circulating adiponectin and supported by the tendency to restore the NAFLD-induced loss of mitochondrial ATP. In addition, silymarin treatment 
significantly improved all indicators of inflammation that were heightened by the induction of NAFLD. Indeed, the infiltration of immune cells into liver tissue was significantly diminished and circulating TNF- $\alpha$ IL-1ß and IL-6 levels were remarkably reduced (Saller et al., 2001; Ligeret et al., 2007; El-Sheikh \& Abd ElFatta, 2011; Haddad et al., 2011; Schrieber et al., 2011; Yao et al., 2011; Girish \& Pradhan, 2012; Kim et al., 2012; Rahimi et al., 2012 and Thounaojam et al., 2012).

Generally, taurine supplementation may be beneficial in preventing various metabolic disorders including obesity, atherosclerosis and insulin resistance (Xiao et al., 2008; Chen et al. , 2009; Gentile et al., 2011 and Rashid et al., 2013) and protecting cells in vitro against various types of injury (Warskulat et al., 2006 and Heibashy \& El-Nahrawy, 2011).

In the current work, the non-alcoholic fatty liver disease (NAFLD) subgroup rats which treated (i.p.) with $500 \mathrm{mg}$ taurine/kg body weight for one and two months recorded significant $(\mathrm{p}<0.05)$ decreases in the levels of serum glucose and insulin as well as in the insulin resistance (HOMA-IR) value associated with a significant decline in the liver glycogen content as shown in Table (2) dependent on the time of treatment ( $1 \& 2$ months). However, taurine is a considerably potent hypoglycemic agent. Since, its suggested that taurine acts on rebuilding the architect of B-cell of Langerhans island, improving the insulin receptor, regulating membrane permeability, increasing membrane stability, decreasing the formation of glycated end products (GEPs) and elevating the antioxidant immune system. These data are in agreement with those of Kiruthiga et al. (2007); Haddad et al. (2011); Rahimi et al. (2012) and Thounaojam et al. (2012). They recorded that insulin sensitivity was restored by taurine treatment as suggested by normalized insulinemia and HOMA-IR through decreasing the ER stress, inflammation and free radicals production, despite the continued intake of the NAFLD-inducing high fructose/fat diet. This hypoinsulinemic effect was shown in several recent previous trials on NAFLD in rats (Chen et al., 2009; Schaffer et al., 2009; Nivala, 2011; Hajiaghamohammadi et al., 2012; Gupta, 2013 and Rashid et al., 2013).

Data of lipid profile in Table (3) revealed that there was a significant $(\mathrm{p}<0.05)$ decrease in the levels of serum total cholesterol, triglycerides, free fatty acids and leptin as well as the liver lipid and cholesterol contents associated with a considerable increment in the serum level of adiponectin in NAFLD rats group after injected intraperitoneally (i.p) with $500 \mathrm{mg}$ taurine $/ \mathrm{kg}$ body weight compared to the corresponding control rats. These results may be attributed to the antioxidant properties of taurine which acts as free radical scavenger, decreases the formation of lipid peroxidation, improves the immune system, inhibits the absorption of lipids in the intestine, enhancement in the hypothalamus-pitutary-thyroid axis (HPTA), increases the conversion of cholesterol to bile acid as a result of enhancement of 7- $\alpha$ hydroxylase and modulates the rate limiting enzyme of hepatic cholesterol catabolism by the enhancement of LDL receptor binding in the liver.

Furthermore, administration of taurine into NAFLD patients or rats induced a reduction in serum and liver triglycerides. The previous observation was likely due to taurine inhibition of acyl-Co-A synthetase, the key enzyme in hepatic triglyceride synthesis proved that the increment of dietary taurine concentration decreases the 
liver lipid content and the high hepatic cellular levels of taurine can modulate the mobilization of liver lipid stores and the utilization of circulating free fatty acids by the liver (Saller et al., 2001 \& 2007; Xiao et al., 2008; Chen et al., 2009; Schaffer et al., 2009; Haddad et al.2011; Rahimi et al. 2012; Gupta, 2013; Rashid et al., 2013 and Kwon et al. 2014).

In the current work, taurine caused apparent improvement in liver functions as shown in Table (4) by restoring total protein and albumin levels that were decreased by high fructose/fat diet associated with a considerable enhancement in the activities of serum AST and ALT as well as a remarkable correction in the haptoglobin production. These data may be attributed the unique chemical structure and physical properties of taurine which improves the synthesis of protein via DNA synthesis, reduction of pro-oxidant formation, enhancement in the activities of enzymes antioxidants, modulation in SH-bond, correction in the skeleton of hepatic cells, amelioration in the glutathione pool or/and the activation of serine/threonine kinase cascades such as c-Jun N-terminal kinase and nuclear factor-kappa- $\beta$ that, in turn, phosphorylate multiple targets, including the insulin receptor and the insulin receptor substrate (IRS) proteins. These data are in harmony with those obtained by Chen et al. (2009); Schaffer et al. (2009); Gentile et al. (2011) and Rashid et al. (2013).

Furthermore, taurine is the principal biological methyl donor, the precursor of aminopropyl groups used in polyamine synthesis, and a provider of cysteine for synthesis of GSH. Experimental evidence also suggests that an additional role of taurine may be its action as a direct antioxidant (Chen et al., 2006). Likewise, taurine is effective antioxidant by acting directly on scavenging hydroxyl radical (Kwon et al., 2014). The mechanisms by which taurine exerts its beneficial effects are unknown, although several possibilities exist. Moreover, substantial evidence indicates that taurine protects a wide variety of cells from oxidative damage by increasing antioxidant defense systems (Nonaka et al., 2001; Vohra \& Hui, 2001 and Heibashy \& Sharoud, 2008), decreasing the formation of reactive oxygen species ( $\boldsymbol{L}$ et al., 2009 and Schaffer et al., 2009) and interfering with reactive oxygen species activity (Merezak et al., 2001).

As shown in Table (5), supplementation of taurine (500mg taurine injected intraperitoneally $/ \mathrm{kg}$ body weight) after induction of NAFLD to rats showed a significant $(\mathrm{p}<0.05)$ decrease in the serum cytokines profile (TNF- $\alpha$, IL-1ß \& IL-6) levels through the whole experiment periods (One and two months). These results are in harmony with those obtained by Kiruthiga et al. (2007); Saller et al. (2007); Xiao et al. (2008); Haddad et al. (2011) and Rahimi et al. (2012). These data may be due to the antioxidant effects of taurine through reduction in the pro-oxidants and free radicals formation, the improvement in the immune system, the enhancement in the insulin receptor signal transduction, the correction in the collagen and hyaluronic acid (HA) levels, modulation in the mitochondrial function via incresing the $\beta$-oxidation of fatty acids in the matrix of mitochondria with enhancement in the activity of acylCoA oxidase, improving the respiratory chain with elevation of ATP synthesis as well as correction in the endoplasmic reticulum by CYP-2E1 and CYP4A isoforms or ER protein folding, reduction in the Malloy bodies synthesis associated with the 
enhancement of LDL receptor binding in the liver and elevation in the adiponectin level.

Co-administration of silymarin and taurine to the NAFLD rats caused maximum correction effects on all studied parameters dependent on the time of treatment (One and two months). These results may be attributed to the synergistic effects of both silymarin and taurine. However, taurine improves the pharmadynamics and pharmakinetics properties of silymarin due to the presence of suphonic group which is a characteristic feature and unique group. For this reason, taurine administration to NAFLD rats may lead to improvement of the physiological, biochemical and pharmalogical properties of silymarin by increasing the activity of lipooxygenase acting together as free radical scavengers, cell membrane stabilizers, hypolipidemic agents and improvements in the auto-immune system.

Table (5): Amelioration effects of silymarin, taurine and their mixture on serum cytokines profile in NAFLD rats (Mean \pm SE).

\begin{tabular}{|c|c|c|c|c|c|c|}
\hline \multicolumn{2}{|c|}{ Parameters } & Control & NAFLD & $\begin{aligned} & \text { NAFLD } \\
& \text { +Silymarin }\end{aligned}$ & $\begin{array}{l}\text { NAFLD } \\
+ \text { Taurine }\end{array}$ & $\begin{array}{l}\text { NAFLD } \\
+ \text { Mixture }\end{array}$ \\
\hline \multirow[t]{2}{*}{$\begin{array}{l}\text { Rat TNF-a } \\
(\mathrm{pg} / \mathrm{ml})\end{array}$} & $\begin{array}{c}\text { 1month } \\
n=5\end{array}$ & $\begin{array}{c}5.175 \\
\pm 0.048^{\mathrm{A}} \\
\end{array}$ & $\begin{array}{c}10.129 \\
\pm 0.078^{\mathrm{B}} \\
\end{array}$ & $\begin{array}{r}8.282 \\
\pm 0.058^{\mathrm{C}} \\
\end{array}$ & $\begin{aligned} & 9.005^{\mathrm{D}} \\
& \pm 0.067_{\mathrm{a}}^{\mathrm{a}} \\
&\end{aligned}$ & $\begin{array}{c}7.537 \\
\pm 0.056^{\mathbf{E}} \\
\end{array}$ \\
\hline & $\begin{array}{c}\text { 2months } \\
n=5\end{array}$ & $\begin{array}{c}5.178 \\
\pm 0.049_{a}^{\mathrm{A}} \\
\end{array}$ & $\begin{array}{r}9.096 \\
\pm 0.071^{\mathrm{B}}{ }_{\mathrm{b}} \\
\end{array}$ & $\begin{array}{r}6.778 \\
\pm 0.053^{C} \\
\end{array}$ & $\begin{aligned} & 8.174 \\
& \pm 0.061^{\mathrm{D}} \\
&\end{aligned}$ & $\begin{array}{r}5.202 \\
\pm 0.048^{\mathrm{A}}{ }_{\mathrm{b}} \\
\end{array}$ \\
\hline \multirow[t]{2}{*}{$\begin{array}{l}\text { Rat IL-1B } \\
(\mathrm{pg} / \mathrm{ml})\end{array}$} & $\begin{array}{c}\text { 1month } \\
n=5\end{array}$ & $\begin{aligned} & 3.802 \\
& \pm 0.037_{\mathrm{a}}^{\mathrm{A}} \\
&\end{aligned}$ & $\begin{array}{c}6.291 \\
\pm 0.061_{\mathrm{a}}^{\mathbf{B}} \\
\end{array}$ & $\begin{aligned} & 5.118 \\
& \pm 0.048^{C} \\
&\end{aligned}$ & $\begin{aligned} & 5.122 \\
& \pm 0.049^{C} \\
&\end{aligned}$ & $\begin{aligned} & 4.447 \\
& \pm 0.043^{\mathrm{D}} \\
&\end{aligned}$ \\
\hline & $\begin{array}{c}\text { 2months } \\
\text { n }=5\end{array}$ & $\begin{aligned} & 3.802 \\
& \pm 0.037_{\mathrm{a}}^{\mathrm{A}} \\
&\end{aligned}$ & $\begin{aligned} & 5.612 \\
& \pm 0.054^{\mathbf{B}}{ }_{b} \\
&\end{aligned}$ & $\begin{array}{r}4.006 \\
\pm 0.041_{b}^{C} \\
\end{array}$ & $\begin{aligned} & 4.321 \\
& \pm 0.044_{b}^{\mathrm{D}} \\
&\end{aligned}$ & $\begin{array}{r}3.795 \\
\pm 0.039^{\mathbf{E}} \\
\end{array}$ \\
\hline \multirow[t]{2}{*}{$\begin{array}{c}\text { Rat IL-6 } \\
(\mathrm{pg} / \mathrm{ml})\end{array}$} & $\begin{array}{c}1 \text { month } \\
n=5\end{array}$ & $\begin{array}{c}10.509 \\
\pm 0.077_{\mathrm{a}}^{\mathrm{A}}\end{array}$ & $\begin{array}{c}19.227 \\
\pm 0.109^{\mathbf{B}} \\
\end{array}$ & $\begin{array}{r}15.388 \\
\pm 0.085^{\mathrm{C}} \\
\end{array}$ & $\begin{array}{r}16.559 \\
\pm 0.092^{\mathrm{D}} \\
\end{array}$ & $\begin{array}{r}14.407 \\
\pm 0.091^{\mathbf{E}} \\
\end{array}$ \\
\hline & $\begin{array}{c}2 \text { months } \\
n=5\end{array}$ & $\begin{array}{c}10.521 \\
\pm 0.079^{\mathrm{A}}\end{array}$ & $\begin{array}{c}16.465 \\
\pm 0.098^{B}{ }_{b}\end{array}$ & $\begin{array}{c}12.227 \\
\pm 0.072^{C}{ }_{b}\end{array}$ & $\begin{array}{c}13.532 \\
\pm 0.089^{\mathrm{D}}{ }_{\mathrm{b}}\end{array}$ & $\begin{array}{c}10.610 \\
\pm 0.081_{b}^{A}\end{array}$ \\
\hline
\end{tabular}

- A, B, C, D, E Means with a common superscript within a row are significantly different at $(\mathbf{P}<0.05)$.

- a, b Means with a common subscript within a column are significantly different at $(P<0.05)$.

From the data of the current study, it could be concluded that the relation between adipose tissue and liver is emerging and may act as a major player in the link between metabolic syndrome and fatty liver disease. Thus, the changes of adipohormones levels provide the additional tool for NAFLD detection. Furthermore, the administration of antioxidants (silymarin or/and taurine) to NAFLD rats proved to have better protective action against non-alcoholic fatty liver disease. silymarin has an important mitochondrial detoxification effect on hepatocytes and other cells as well as regeneration of liver cells . It improved symptoms of NAFLD and might correct metabolic conditions. Taurine, on the other hand, acts as free radical scavenger, cell membrane stabilizer and lipid peroxidation reduction dependent on the time of duration.

\section{Conclusion}

\section{Acknowledgement}




\section{References}

Aghazadeh, S.; Amini, R.; Yazdanparast, R. and Ghaffari, H. (2011): Anti-apoptotic and anti-inflammatory effects of Silybum marianum in treatment of experimental steatohepatitis. Exp. Toxicol. Pathol.; 63(6):569-574.

Allen, P. (2010): The effect of drugs and nutraceuticals on the prevention and treatment of non-alcoholic fatty liver disease using rats as a model for humans. M. Sc. Thesis; Nutritional Sciences (Animal Nutrition) Department, Iowa State University, Iowa, USA.

Angulo, P. (2002). Nonalcoholic fatty liver disease. N. Engl. J. Med; 346: 1221-1231. Angulo, P. (2007): GI epidemiology: nonalcoholic fatty liver disease. Aliment. Pharmacol. Ther.; 25: 883-889.

Basiglio, C.; Sanchez, A.; pozzi, A.; Mottino, D. and Roma, D. (2009): Differential effects of silymarin and its active component silibinin on plasma membrane stability and hepatocellular lysis. Chemico-Biological Interactions; 179:297303.

Bays, H.E.; Chair, F. and Toth, P. (2013): Obesity, adiposity, and dyslipidemia: A consensus statement from the National Lipid Association. J. Clin. Lipidology; 7:304-383.

Bellantini, S.; Pecorari, M.; Cordoma, P.; Marchegiano, P.; Manenti, F.; Bosisio, E.; De Fabiani, E. and Galli, G. (1987): Taurine increases bile acid pool size and reduces bile saturation index in the hamster. Journal of Lipid Research; 28: 1021-1027.

Bogdanova, K.; Poczatkova, H.; Uherkova, L.; Riegrova, D.; Rypka, M.; Feher, J.; Marchesini, G. and Vesely, J. (2006): Nonalcoholic fatty liver disease (NAFLD): A Novel common aspect of the metabolic syndrome. Biomed. Pap; 150(1): 101-104.

Brown, M. \& Goldstein, J. (1997): The SREBP pathway: regulation of cholesterol metabolism by proteolysis of a membrane-bound transcription factor. Cell; 89:331-340.

Brumbaughff, D. and Friedmanff, J. (2014): Developmental origins of nonalcoholic fatty liver disease. Pediatric Research; 75:140-147.

Bruns, H.; Watanpour, I. and Gebhard, M. (2011): Glycine and taurine equally prevent fatty livers from Kupffer cell-dependent injury: an in vivo microscopy study. Microcirculation; 18:205-213.

Chen, S.; Chen, Y. and Zhang, X. (2006): The prevention and therapeutic effect of taurine on experimental rat nonalcoholic fatty livers. Zhonghua Gan Zang Bing Za Zhi; 14:226-227.

Chen, X.; Sebastian, B.; Tang, H.; McMullen, M. and Axhemi, A. (2009): Taurine supplementation prevents ethanol-induced decrease in serum adiponectin and reduces hepatic steatosis in rats. Hepatology; 49:1554-1562. 
Chitturi, S.; Farrell, G. and Frost, L. (2002): Serum leptin in NASH correlates with hepatic steatosis but not fibrosis: a manifestation of lipotoxicity? J. Hepatol; 36:403-409.

Choudhuri, G. (2013): Introduction and clinical implications. Chapter 1 in NonAlcoholic Fatty Liver Disease: A Clinical Spectrum, Ed G Choudhuri, ECAB Clinical Update: Gastroenterology/Hepatology, Elsevier; 1-17.

Cosma, M. (2014): The Impact of Cytokines and Chemokines on Non-Alcoholic Fatty Liver Disease (NAFLD). Biotechnology, Molecular Biology and Nanomedicine; 2(1): 15-16.

Crews, F.; Bechara, R.; Brown, L.; Guidot, D. and Mandrekar, P. (2006): Cytokines and alcohol. Alcohol Clin. Exp. Res; 30:720-730.

Cusi K. (2012): Role of obesity and lipotoxicity in the development of nonalcoholic steatohepatitis: pathophysiology and clinical implications. Gastroenterology; 142:711-725.

Das, S. and Balakrishnan, V. (2011): Role of Cytokines in the Pathogenesis of NonAlcoholic Fatty Liver Disease. Ind. J. Clin. Biochem; 26(2):202-209.

Datta, S.; Sinha, S. and Bhattacharya, P. (1999): Hepatoprotective activity of an herbal protein CI-1, purified from Cajanus indicus against galactosamine $\mathrm{HCl}$ toxicity in isolated rat hepatocytes. Phtother. Res; 13:508-512.

Douali, N.; Abdennour, M.; Zucker, J. and Jaulent, M. (2014): Formalization of Clinical Practice Guidelines: Nonalcoholic Steatohepatitis Diagnosis ModelRelated Personalized Medicine. EJBI; 10(1): 6-10.

Du Vigneaud, V. and Karr, W. (1925): Carbohydrate utilisation. Rate of is appearance of D-glucose from the blood. J. Biol. Chem; 66:281-300.

Duncan, D.B. (1955): Multiple ranges and multiple F- test. Biometric; 11: 1 - 42.

Eckel, R.H., Grundy, S.M. and Zimmet, P.Z. (2005): The metabolic syndrome. Lancet; 365:1415-1428.

Elitok, B. (2012): Efficacy of Herbal Remedies in the Treatment of Nonalcholic Fatty Liver Disease/Hepatic Steatosis in Human and Animals. Kocatepe Vet. J.; 5(2): 49-53.

El-Sheikh, N. and Abd El-Fatta, H. (2011): Counteracting Methionine CholineDeficient Diet-induced Fatty Liver by Administration of Turmeric and Silymarin. J. Applied Sci. Res.; 7(12):1812-1820.

Gentile, C.; Nivala, A.; Gonzales, J.; and Pfaffenbach K. (2011): Experimental evidence for therapeutic potential of taurine in the treatment of nonalcoholic fatty liver disease. Am. J. Physiol. Regul. Integr. Comp. Physiol.; 301(6):R1710-22.

George, J.; Pera, N.; Phung, N.; Leclercq, I.; Hou, J. and Farrel, G. (2003): Lipid peroxidation, stellate cell activation and hepatic fibrogenesis in a rat model of chronic steatohepatitis. J. Hepatology; 39:756-764.

Ginsberg, H.; Zhang, Y. and Hernandez-Ono, A. (2005): Regulation of plasma triglycerides in insulin resistance and diabetes. Arch. Med. Res.; 36(3): 232240. 
Girish, C. and Pradhan, S. C. (2012): Hepatoprotective activities of picroliv, curcumin, and ellagic acid compared to silymarin on carbon-tetrachlorideinduced liver toxicity in mice. J. Pharmacology and Pharmacotherapeutics; 3(2): 149-155.

Go, R.; Desmond, R.; Roseman, J.; Bell, D.; Vanichanan, C. and Acton, R. (2001): Prevalence and risk factors of microalbuminuria in a cohort of AfricanAmerican women with gestational diabetes. Diabetes Care; 24(10): 17641769.

Grattagliano, I.; Vendemiale, G. and Caraceni, P. (2000): Starvation impairs antioxidant defense in fatty livers of rats fed a choline-deficient diet. J. Nutr.; 130:2131-2136.

Gupta, R. (2013): Changing life style and diabetes; Taurine- components of functional food and nutraceuticals. $13^{\text {th }}$ International Conference of ASFFBC: Science and Practical Application, Kyoto University of Medicine, Kyoto, Japan.

Gylling, H.; Hallikainen, M. and Pihlajamäki, J. (2010): Insulin sensitivity regulates cholesterol metabolism to a greater extent than obesity: lessons from the METSIM study. J. Lipid Res.; 51(8): 2422-2427.

Haddad, H.; Vallerand, D.; Brault, A. and Haddad, P. (2011): Antioxidant and Hepatoprotective Effects of Silibinin in a Rat Model of Nonalcoholic Steatohepatitis. Evidence-Based Complementary and Alternative Medicine, ; Article ID: 647903-647913.

Hajiaghamohammadi, A.; Ziaee, A.; Oveisi, S. and Masroor, H. (2012): Effects of metformin, pioglitazone and silymarin treatment on non-alcoholic Fatty liver disease: a randomized controlled pilot study. Hepat. Mon.; 12(8):e6099-e7005.

Hebbard, L. and George, J. (2011): Animal models of nonalcoholic fatty liver disease. Nat. Rev. Gastroenterol. Hepatol.; 8: 35-44.

Heibashy, M.I. and Sharoud, M.N. (2008): Attenuation of the disruptive effects induced by $\gamma$-irradiation in rats using ozonated water and/or taurine. Isotope Rad. Res; 40:1527-1541.

Heibashy, M.I. and El-Nahrawy, W.A. (2011): Possible Synergistic Therapeutic Role of Taurine and Curcumin on Cerulein-Induced Acute Pancreatitis in Rats. J. Am. Sci.; 7(7):485-495.

Heibashy, M.I.; Zaki, N.A. and. El-Nahrawy, W.A. (2010): Alterations in insulin, leptin, orexin and neuropeptide-Y levels in the high-fat diet fed rats. Austral. J. Basic and Applied Sci; 4(6): 1473-1481.

Heibashy, M.I.; Mazen, G.M. Kelada, A.A. (2013): Insulin resistance induced by a high fructose diet in rats due to hepatic disturbance. Arab J. Nucl. Sci. Appl.; 46(3):297-306.

Houstis, N.; Rosen, E. and Lander, E. (2006): Reactive oxygen species have a casual role in multiple forms of insulin resistance. Nature; 440:944-948.

Hui, J.; Hodge, A.; Farrell, G.; Kench, J.; Kriketos, A. and George, J. (2004): Beyond insulin resistance in NASH: TNF-alpha or adiponectin? Hepatology; 40(1):4654. 
Ishii, S.; Ilzuka, K.; Miller, B. and Uyeda, K. (2004): Carbohydrate response element binding protein directly promotes lipogenic enzyme gene transcription. Proceedings of the National Academy of Sciences of the United States of America; 101(44): 15597-15602.

Jaya, C.; Vetriselvi, V. and Anuradha, C. (2010): Inflammatory responses in liver induced by high fat plus fructose diet: therapeutic potential of Cissus quadrangularis stem. Int J Biol Med Res; 1(4):120-124

Jia, J.; Bauer, M. and Cho, J. (2001): Antifibrotic effect of silymarin in rat secondary biliary fibrosis is mediated by ownregulation of procollagen $\alpha 1$ (I) and TIMP1. J. Hepatology; 35(3):392-398.

Khedmat, H. and Taheri, S. (2011): Non-alcoholic steatohepatitis: An update in pathophysiology, diagnosis and therapy. Hepat Mon.; 11(2):74-78.

Kidd, P. and Head, K. (2005): A review of the bioavailability and clinical efficacy of milk thistle phytosome: a silybin-phosphatidylcholine complex (Siliphos). AlternativeMedicine Review; 10(3):193-203.

Kim, M.; Yang, S.; Kim, J.; Lee, J. and Kem, Y. (2012): Silymarin suppresses hepatic stellate cell activation in a dietary rat model of non-alcoholic steatohepatitis: Analysis of isolated hepatic stellate cells. Int. J. Molecular Med.; 30: 473-479.

Kiruthiga, P.; Shafreen, R.; Pandian, S. and Devi, K. (2007): Silymarin protection against major reactive oxygen species released by environmental toxins: exogenous $\mathrm{H} 2 \mathrm{O} 2$ exposure in erythrocytes. Basic Clin Pharmacol Toxicol.; 100(6):414-419.

Kosina,, P.; Kren, V.; Gebhardt, R.; Grambal, F.; Ulrichova, J. and Walterova, D. (2002): Antioxidant properties of silybin glycosides. Phytother Res; 16: S33S39.

Kulkarni, Y.; Yele, V.; Addepalli, V. and Kulkarni, K. (2012): Non-alcoholic fatty liver disease: Introspection. Pharmacologyonline; 105: 104-112.

Kwon, D.; Jung, Y.; Kim, S. and Park, H. (2014): Impaired Sulfur-Amino Acid Metabolism and Oxidative Stress in Nonalcoholic Fatty Liver Are Alleviated by Betaine Supplementation in Rats. J. Nutrition, Under Publication

Li, Y.; Arnold, J.; Pampillo, M.; Babwah, A. and Peng, T. (2009): Taurine prevents cardiomyocyte death by inhibiting NADPH oxidase-mediated calpain activation. Free Radic Biol Med; 46:51-61.

Ligeret, H.; Brault, A.; Vallerand, D.; Haddad Y. and Haddad, P. (2007): Antioxidant and mitochondrial protective effects of silibinin in cold preservation-warm reperfusion liver injury. J. Ethnopharmacology; 115:507-514.

Ludwig, J.; Viggiano, T.; McGill, D. and Oh B. (1980): Nonalcoholic steatohepatitis: Mayo Clinic experiences with a hitherto unnamed disease. Mayo Clin Proc; 55:434-8.

Machado, M.V. and Cortez-Pinto, H. (2013): Non-invasive diagnosis of nonalcoholic fatty liver disease. J. Hepato.; 58:1007-1019.

Matsuzawa, N.; Takamura, T. and Kurita, S. (2007): Lipid-induced oxidative stress causes steatohepatitis in mice fed an atherogenic diet. Hepatology; 46(5):1392-1403. 
Matthews DR, Hosker JP, Rudenski AS (1985): Homeostasis model assessment: insulin resistance and beta-cell function from fasting plasma glucose and insulin concentrations in man. Diabetologia; 412: $9-28$.

Mauss, S.; Berg, T.; Rockstroh, J.; Sarrazin, C. and Wedemeyer, H. (2014): Hepatology "A Clinical Textbook", Flying Publisher. ISBN: 978-3-92477491-2 Printed in Germany by Druckhaus Süd.

Merezak, S.; Hardikar, A.; Yajnik, C.; Remacle, C. and Reusens, B. (2001): Intrauterine low protein diet increases fetal B-cell sensitivity to NO and IL-1B: the protective role of taurine. J Endocrinol; 171:299-308.

Miller, A. and Adeli, K. (2088): Dietary fructose and metabolic syndrome. Curr. Opin. Gastroenterol; 24: 204-209.

Milton, J.S.; Cobert, J.J. and Mc-Teer, P.M. (1986): "Introduction to Statistic" 3rd ed. D.C. Health and company. Canada.

Minglan, L.; Reynolds, C; Sloboda, D.; Gray, C. and Vickers, M. (2013): Effects of Taurine Supplementation on Hepatic Markers of Inflammation and Lipid Metabolism in Mothers and Offspring in the Setting of Maternal Obesity. PLOS ONE 8(10): e76961- e76969.

Miura, K.; Kodama, Y. and Kodama, Y.S. (2010): Toll-like receptor 9 promotes steatohepatitis via induction of interleukin-1 $\beta$ in mice. Gastroenterology; 139(1):323-334.

Nakagawa, T.; Muramoto, Y.; Hori, M.; Mihara, S.; Marubayashi, T. and Nakagawa, K. (2008): Preliminary investigation of the association between haptoglobin polymorphism, serum ferritin concentration and fatty liver disease. Clin Chem Acta; 398:34-38.

Nivala, A. (2011): Dissertation novel therapies for NAFLD. Thesis Doctor of Philosophy, Colorado State University, Fort Collins, Colorado

Nonaka, H.; Tsujino, T.; Watari, Y.; Emoto, N. and Yokoyama, M. (2001): Taurine prevents the decrease in expression and secretion of extracellular superoxide dismutase induced by homocysteine: amelioration of homocysteine-induced endoplasmic reticulum stress by taurine. Circulation; 104:1165-1170.

Olofsson, S.; Stillemark-Billton, P. and Asp, L. (2000): Intracellular assembly of VLDL: two major steps in separate cell compartments. Trends in Cardiovascular Medicine; 10(8):338-345.

Ong, J.P.; Pitts, A. and Younossi, Z. (2008: Increased overall mortality and liverrelated mortality in non-alcoholic fatty liver disease. J Hepatol; 49(4):608-12.

Onnerhag, K.; Nilsson, P. and Lindgren, S. (2013): Insulin resistance with impaired fasting glucose increases the risk of NAFLD. Open Journal of Gastroenterology; 3:170-176.

Ota, T.; Gayet, C. and Ginsberg, H. (2008): Inhibition of apolipoprotein $\$ 100$ secretion by lipid-induced hepatic endoplasmic reticulum stress in rodents. J Clin Invest; 118:316-332.

Ouyang, X.; Cirillo, P. and Sautin, Y. (2008): Fructose consumption as a risk factor for non-alcoholic fatty liver disease. J Hepatol 48: 993-999. 
Pagano, C.; Soardo, G. and Pilon, C. (2006): Increased serum resistin in non-alcoholic fatty liver disease is related to liver disease severity and not to insulin resistance. J Clin Endocrin Metabol; 10:1210-1217.

Parildar-Karpuzoglu, H.; Mehmetcik, G. and Ozdemirler-Erata, G. (2008): Effect of taurine treatment on pro-oxidant-antioxidant balance in livers and brains of old rats. Pharmacol Rep; 60:673-678.

Peet, D.; Janowski, B. and Mangelsdorf, D. (1998): The LXRs: a new class of oxysterol receptors. Current Opinion in Genetics and Development; 8(5):571575.

Pooranaperundevi, M.; Sumiyabanu, M.; Viswanathan, P.; Sundarapandiyan, R. and Anuradha, C. (2010): Insulin resistance induced by a high-fructose diet potentiates thioacetamide hepatotoxicity. Singapore Med J.; 51(5):389-98.

Possamai, L.A.; Thursz, M.R.; Wendon, J.A. and Antoniades, C.G. (2014): Modulation of monocyte/macrophage function: a therapeutic strategy in the treatment of acute liver failure. J. Hepatology (Under publication).

Rahimi, H.; Gholami, M.; Khorram-Khorshid, H.; Gharibdoost, F. and Abdollahi, M. (2012): On the protective effects of IMOD and Silymarin combination in a rat model of acute hepatic failure through anti-oxidative stress mechanisms. Asian Journal of Animal and Veterinary Advances; 7(1):38-45.

Rashid, K.; Das, J. and Sil, P. (2013): Taurine ameliorates alloxan induced oxidative stress and intrinsic apoptotic pathway in the hepatic tissue of diabetic rats. Food Chem Toxicol.; 51:317-329.

Reaven, G. (1994): Syndrome X: 6 years later. J. Internal Med.; 236:13-22.

Renganathan A. (1999): Pharmaco dynamic properties of andrographolide in experimental animals. MD thesis; Pharmacology. Pondicherry: Jawaharlal Institute of Postgraduate Medical Education \& Research (JIPMER), Pondicherry University; 1999.

Rezazadeh, A. and Yazdanparast, R. (2014): Prevention of Nonalcoholic Steatohepatitis in Rats by Two Manganese-Salen Complexes. Iranian Biomedical Journal 18 (1): 41-48

Saller, R.; Meier, R. and Brignoli, R. (2001): The use of silymarin in the treatment of liver diseases. Drugs; 61: 2035-2063.

Saller, R.; Melzer, J.; Reichling, J. Brignoli, R. and Meier, R. (2007): An updated systematic review of the pharmacology of silymarin. Forschende Komplementarmedizin; 14(2):70-80.

Samuel, V.T., Liu, Z.X., Qu, X., Elder, B.D., Bilz, S., Befroy, D., Romanelli, A.J., and Shulman, G.I. (2004). Mechanism of hepatic insulin resistance in nonalcoholic fatty liver disease. J. Biol. Chem. 279, 32345-32353.

Samuel, V.T., Liu, Z.X., Wang, A., Beddow, S.A., Geisler, J.G., Kahn, M., Zhang, X.M., Monia, B.P., Bhanot, S., and Shulman, G.I. (2007). Inhibition of protein kinase Cepsilon prevents hepatic insulin resistance in nonalcoholic fatty liver disease. J. Clin. Invest. 117, 739-745.

Schaffer, S.; Azuma, J. and Mozaffari, M. (2009): Role of antioxidant activity of taurine in diabetes. Can J Physiol Pharmacol; 87:91-99. 
Schattenberg, M. and Galle, R. (2010): Animal models of non-alcoholic teatohepatitis of mice and man. Dig Dis. 28: 247-254.

Schrieber, S.; Hawke, R.; Wen, Z. and Smith, P (2011): Differences in the Disposition of Silymarin between Patients with Nonalcoholic Fatty Liver Disease and Chronic Hepatitis C. Drug Metab. Dispos.; 39(12): 2182-2190.

Sebastiani, G.; Ghali, P. and Wong, P. (2014): Physicians' practices for diagnosing liver fibrosis in chronic liver diseases. Canadian Journal of Gastroenterology; 28(1):23-30.

Shimano, H.; Horton, J.; Shimomura, I.; Hammer, R.; Brown, M. and Goldstein, I (1997): Isoform 1c of sterol regulatory element binding protein is less active than isoform-1 $\alpha$ in livers of transgenic mice and in cultured cells. J. Clin. Invest; 99(5):846-854.

Shimomura, I.; Bashmakov, Y. and Horton, J. (1999): Increased levels of nuclear SREBP-1c associated with fatty livers in two mouse models of diabetes mellitus. J Biol Chem; 274:30028-30032.

Simonen, P.; Hotronen, A. and Hallikainen, M. (2011): Cholesterol synthesis is increased and absorption decreased in non-alcoholic fatty liver disease independent of obesity. J. Hepatology; 54(1):153-159.

Snedecor, G.W. and Cochran, W.G. (1982): "Statistical Methods" $7^{\text {th }}$ ed. Two state University press, Ames Iowa, U.S.A.

Sookoian, S. and Pirola, C. (2014): NAFLD: Metabolic make-up of NASH: from fat and sugar to amino acids. Gastroenterology \& Hepatology; 11: 205-207.

Targher, G.; Marra, F. and Marchesini, G. (2008): Increased risk of cardiovascular disease in non-alcoholic fatty liver disease: causal effect or epiphenomenon? Diabetologia;51(11):1947-53.

Terao, J. (2009): Dietary flavonoids as antioxidants. Forum of Nutrition; 61:87-94.

Thounaojam, M.; Jadeja, R.; Devkar, R. and Ramachandran, A. (2012): Non-alcoholic steatohepatitis: an overview including treatments with herbals as alternative therapeutics. J. Appl. Biomed.; 10 (3); 119-136.

Tilg, H. and Moschen, A.R. (2008): Insulin resistance, inflammation and nonalcoholic fatty liver disease. Trends in Endocrinology \& Metabolism, 19, 371379.

Uyeda, K.; Yamashita, H. and Kawaguchi, T. (2002): Carbohydrate responsive element-binding protein (ChREBP): a key regulator of glucose metabolism and fat storage. Biochemical Pharmacology; 63(12): 2075-2080.

Victorrajmohan, C.; Pradeep, K. and Karthikeyan, S. (2005): Influence of silymarin administration on hepatic glutathione-conjugating enzyme system in rats treated with antitubercular drugs. Drugs; 6(6):395-400.

Vohra, B. and Hui, X. (2001): Taurine protects against carbon tetrachloride toxicity in the cultured neurons and in vivo. Arch Physiol Biochem; 109:90-94.

Vos, M. and Lavine, J. (2013): Dietary fructose in nonalcoholic fatty liver disease. Hepatology 2013; doi: 10.1002/hep.26299.

Wang, Y.; Lam, K.; Chan, L.; Chan, K. and Lam, J. (2006): Posttranslational modifications of the four conserved lysine residues within the collagenous 
domain of adiponectin are required for the formation of its high molecular weight oligomeric complex. J Biol Chem.; 281:16391-16400.

Warskulat, U.; Borsch, E.; Reinehr, R.; Heller-Stilb, B.; Monnighoff, I. and Buchczyk, D. (2006): Chronic liver disease is triggered by taurine transporter knockout in the mouse. FASEB J; 20:574-576.

Watanabe, S.; Yaginuma, R.; Ikejima, K. and Miyazaki, A. (2008): Liver diseases and metabolic syndrome. J Gastroenterol; 43(7):509-18.

Wohlfahrt, J.; A Fettelschoss, A.; Kundig, T; Hermanns, H and Schmitt, J. (2014): Beneficial effects on weight gain, hepatic steatosis and expression of lipogenic target genes in a murine obesity model after IL-1 type cytokine inactivation. Z. Gastroenterol; 52(3): 301-308.

Xiao, C.; Giacca, A. and Lewis, G. (2008): Oral taurine but not N-acetylcysteine ameliorates NEFA-induced impairment in insulin sensitivity and beta cell function in obese and overweight, non-diabetic men. Diabetologia.; 51(1):139146.

Xiao, J.; So, F.; Liong, C. and Tipoe, L. (2013): Recent Advances in the Herbal Treatment of Non-Alcoholic Fatty Liver Disease. J. Tradit. Complement Med.; 3:88-94.

Xirouchakis, E.; Sigalas, A.; Manousou, P.; Calvaruso, V.; Pleguezuelo, M. and Corbani A. (2008): Models for non-alcoholic fatty liver disease: a link with vascular risk. Curr. Pharm. Des. ; 14:378-384.

Yao, J.; Zhi, M. and Minhu, C. (2011): Effect of silybin on high-fat-induced fatty liver in rats. Braz J Med Biol Res.; 44(7):652-659.

Zhu, L.; Baker, S. and Gill, C. (2013): Characterization of the gut microbiome in nonalcoholic steatohepatitis (NASH) patients: A connection between endogenous alcohol and NASH. Hepatology; 57:601-609. 


\section{الملخص العربى}

\section{الاور العلاجى للسيليمارين أواو التاورين على مرض التشحم الكباى الغير كحولى المرتبط بالأعراض الأيضية فى الجرذان النيان \\ فاطمة محمد عبد المنعم زهـران - منى اسماعيل شـاهين - نفين عاطف قلادة - دينـا محمـــ إسـلام

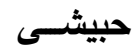 \\ قسم علم الحيو ان - كلية البنات للآداب و العلوم و التربية - جامعة عين شمس}

مرض الكبد الدهنى (التشحم الكبدى) غير الكحولى (NAFLD) هو أحد الأمراض المتلازمة للعملية

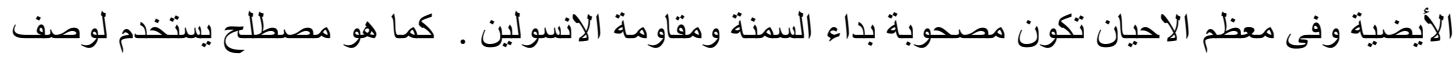

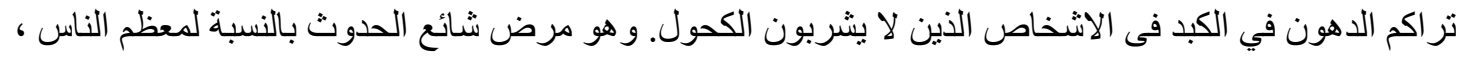

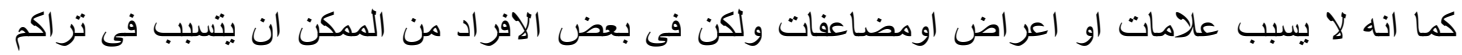

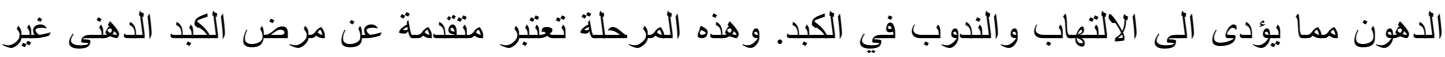

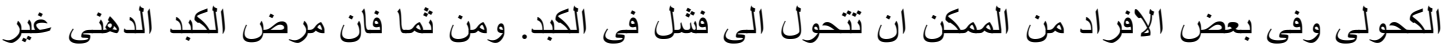

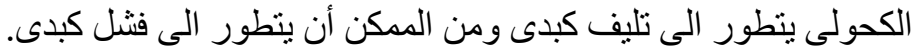

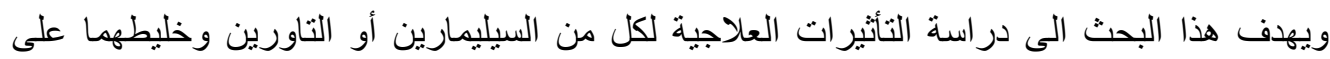

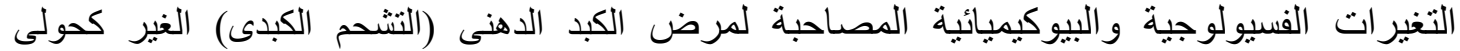

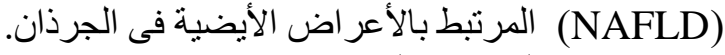

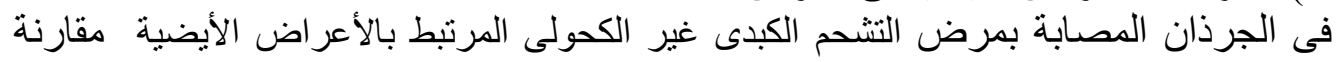

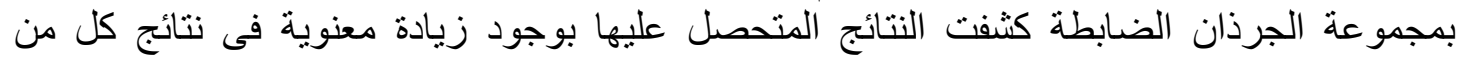

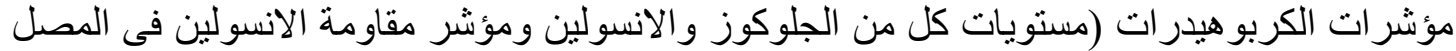

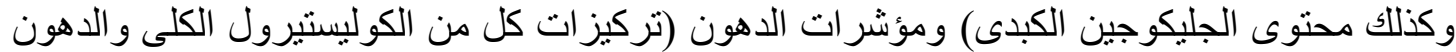

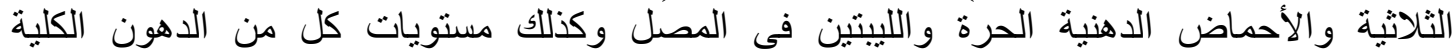
و الكوليستيرول فى الكبد) مع أرتفاع ملحوظ فئ نشاطات الأنزيمات الكبدية الناقل للأحماض الأن الأمينية (ALT \& AST) وزيادة معنوية فى مستوى نتائج الهابتو جلوبين (Haptoglobin).

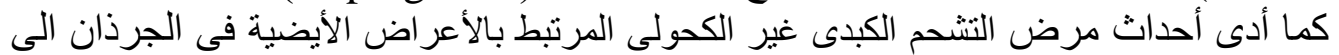

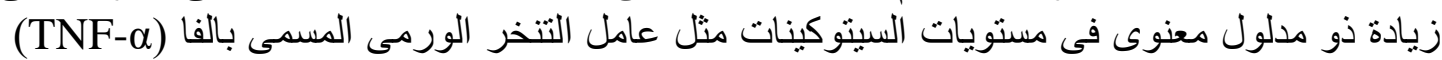

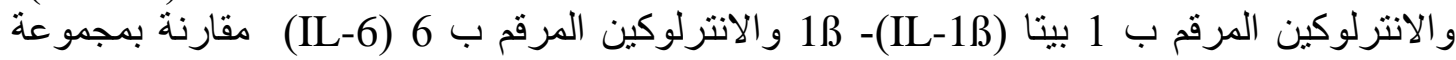

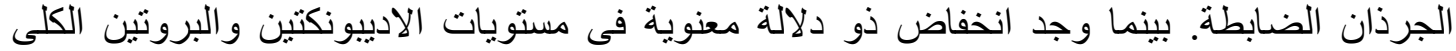
و الالبيومين فى الجرذان المصابة بمرض الكبد الدهنى (التشحم الكبدى) غير الكحولى (NAFLD) مقارئة فئنة بمجموعة الجرذان الضابطة.

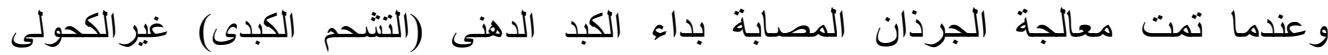
المرتبط بالأعر اض الأيضية فى الجرذان بواسطة السليمارين او التاورين وخليط منهما مما

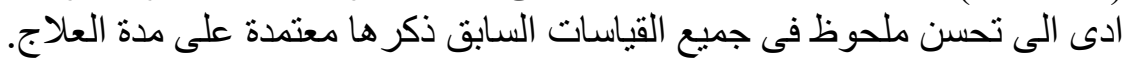

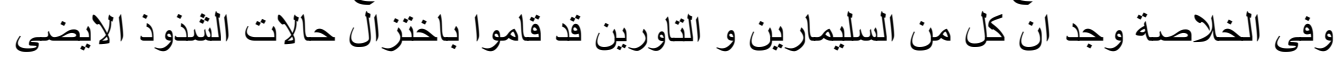

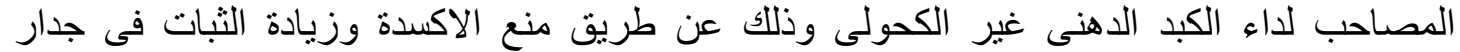

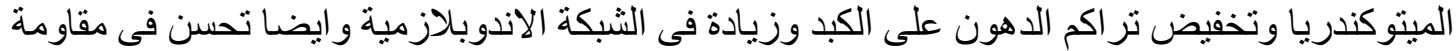

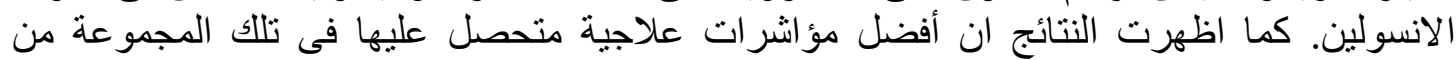

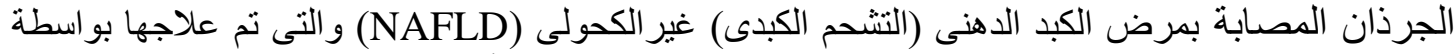

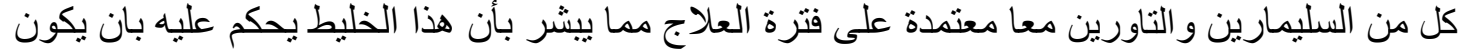
علاج جديد وواعد لداء خطير وشنائع الأو هو مرض التارين الكبد الدهنى (التشحم الكبدى) غير الكحولى. 